\title{
Review \\ The Serine Protease CD26/DPP4 in Non-Transformed and Malignant T Cells
}

\author{
Guranda Chitadze ${ }^{1}$, Ulrike Wehkamp ${ }^{2}$, Ottmar Janssen ${ }^{3}{ }^{(D}$, Monika Brüggemann ${ }^{1}$ and Marcus Lettau ${ }^{1,3, *(1)}$ \\ 1 Unit for Hematological Diagnostics, Department of Internal Medicine II, University Hospital \\ Schleswig-Holstein, Langer Segen 8-10, D-24105 Kiel, Germany; Guranda.Chitadze@uksh.de (G.C.); \\ m.brueggemann@med2.uni-kiel.de (M.B.) \\ 2 Department of Dermatology, University Hospital Schleswig-Holstein, Arnold-Heller-Str. 3, Bldg. C, \\ D-24105 Kiel, Germany; uwehkamp@dermatology.uni-kiel.de \\ 3 Institute of Immunology, University Hospital Schleswig-Holstein, Christian-Albrechts University Kiel, \\ Arnold-Heller-Str. 3, Bldg. U30, D-24105 Kiel, Germany; Ottmar.Janssen@uksh.de \\ * Correspondence: marcus.lettau@uksh.de; Tel.: +49-431-500-31025
}

Citation: Chitadze, G.; Wehkamp, U.; Janssen, O.; Brüggemann, M.; Lettau, M. The Serine Protease CD26/DPP4 in Non-Transformed and Malignant $\mathrm{T}$ Cells. Cancers 2021, 13, 5947. https:// doi.org/10.3390/cancers13235947

Academic Editor: Oscar J. Cordero

Received: 15 November 2021

Accepted: 23 November 2021

Published: 26 November 2021

Publisher's Note: MDPI stays neutral with regard to jurisdictional claims in published maps and institutional affiliations.

Copyright: (c) 2021 by the authors. Licensee MDPI, Basel, Switzerland. This article is an open access article distributed under the terms and conditions of the Creative Commons Attribution (CC BY) license (https:// creativecommons.org/licenses/by/ $4.0 /)$.
Simple Summary: The transmembrane serine protease CD26/Dipeptidylpeptidase 4 modulates T-cell activation, proliferation, and effector function. Due to their remarkable tumoricidal properties CD26-positive $\mathrm{T}$ cells are considered promising candidates for $\mathrm{T}$ cell-based immunotherapies while in cutaneous $\mathrm{T}$ cell lymphoma CD26/DPP4 expression patterns are established markers for diagnosis and possibly prognosis. With a focus on $\mathrm{T}$ cells, we review current knowledge on the regulation of CD26/DPP4 expression and release, its implication in T-cell effector function and the suitability CD26/DPP4 as a diagnostic and/or prognostic factor in T-cell malignancies.

Abstract: CD26/Dipeptidylpeptidase 4 is a transmembrane serine protease that cleaves off $\mathrm{N}$ terminal dipeptides. CD26/DPP4 is expressed on several immune cell types including T and NK cells, dendritic cells, and activated B cells. A catalytically active soluble form of CD26/DPP4 can be released from the plasma membrane. Given its wide array of substrates and interaction partners CD26/DPP4 has been implicated in numerous biological processes and effects can be dependent or independent of its enzymatic activity and are exerted by the transmembrane protein and/or the soluble form. CD26/DPP4 has been implicated in the modulation of T-cell activation and proliferation and CD26/DPP4-positive T cells are characterized by remarkable anti-tumor properties rendering them interesting candidates for T cell-based immunotherapies. Moreover, especially in cutaneous T-cell lymphoma CD26/DPP4 expression patterns emerged as an established marker for diagnosis and treatment monitoring. Surprisingly, besides a profound knowledge on substrates, interaction partners, and associated signal transduction pathways, the precise role of CD26/DPP4 for T cell-based immune responses is only partially understood.

Keywords: CD26; DPP4; dipeptidyl peptidase 4; T cells; cytotoxic granules; cutaneous T-cell lymphoma; mycosis fungoides; Sézary syndrome

\section{Basic Features of CD26/DPP4}

CD26/Dipeptidylpeptidase 4 (DPP4) is a $110 \mathrm{kDa}$ type 2 transmembrane glycoprotein that belongs to the S9 protease family of prolyl oligopeptidases (EC 3.4.14.5) that cleaves off N-terminal dipeptides with penultimate prolines or alanines. The extracellular part of the protein comprises a C-terminal catalytic domain with the catalytic triad $\mathrm{S}_{630}, \mathrm{~N}_{708}$, and $\mathrm{H}_{740}$, a cysteine-rich area and a glycosylated region that is linked to the transmembrane region via a flexible stalk. The extracellular domain also contains binding sites for example for adenosine deaminase (ADA) and components of the extracellular matrix like fibronectin. Of note, only six N-terminal amino acids are predicted to extend into the cytosol. The active 
site $\mathrm{S}_{630}$ is flanked by the classic serine peptidase motif G-W-S ${ }_{630}-\mathrm{Y}-\mathrm{G}-\mathrm{G}-\mathrm{Y}-\mathrm{V}$ (Figure 1) (reviewed in [1-3]).

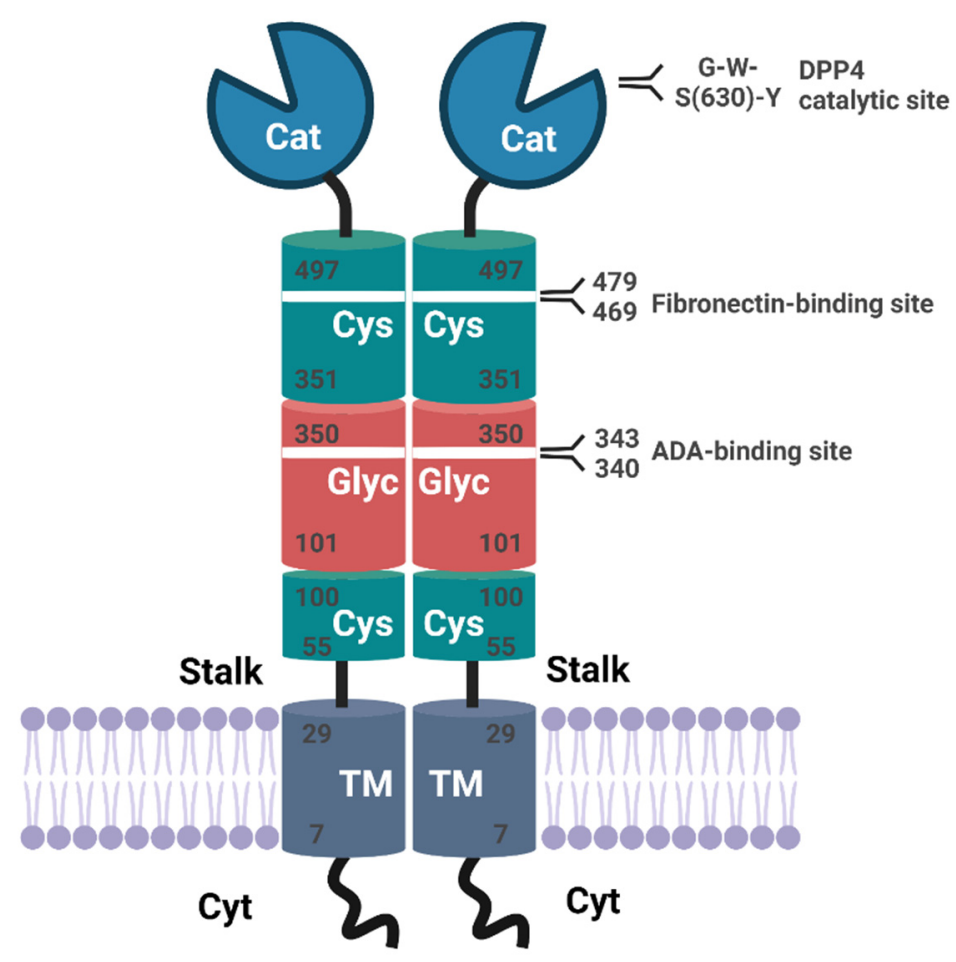

Figure 1. Schematic representation of DPP4 modular structure. Human CD26/DPP4 is a type 2 transmembrane serine protease comprising 766 amino acids (aa). The extracellular catalytic region (Cat, aa 506-766) with the catalytic triad $\mathrm{H}_{740}, \mathrm{~N}_{708}$, and $\mathrm{S}_{630}$ is located at the C-terminus followed by a cysteine-rich region (Cys, aa 351-497), a glycosylated region (Glyc, aa 101-350), another short cysteine-rich region (Cys, aa 55-100), and a flexible stalk region (aa 30-48). The transmembrane domain (TM) encompasses aa 17-29 and only 6 amino acids constitute the N-terminal cytosolic (Cyt) part of the molecule. The extracellular part contains binding sites for interaction partners like adenosine deaminase (aa 340-343) or fibronectin (aa 469-479). Full-length CD26/DPP4 is suggested to be cleaved within its flexible stalk region to release catalytically active soluble CD26/DPP4 (figure adapted from [1]).

Moreover, the C-terminal region, an extracellular propeller loop and the transmembrane region might contribute to CD26 dimerization and enzymatic activity [4]. In addition, dimerization might also modulate protein interactions of the cytoplasmic tail. For example, only dimeric CD26 interacts with CARMA-1 [5]. CD26/DPP4 is rather ubiquitously expressed on blood cells, fibroblasts, mesothelial, epithelial, and endothelial cells and is detected in several organs including placenta, kidney, intestine, prostate, gall bladder, pancreas, and liver [6-8]. In the immune system, CD26/DPP4 is expressed on dendritic cells, activated B cells, natural killer (NK) cells, T cells, and CD34 ${ }^{+}$progenitor cells (reviewed in [1]).

\section{Soluble CD26/DPP4}

A catalytically active soluble form of CD26/DPP4 (sCD26/DPP4) that lacks the intracellular and transmembrane domain is released from the plasma membrane [9] and can be detected in serum, saliva, cerebrospinal and seminal fluid, and bile [10]. The enzymatic CD26/DPP4 activity in serum has been mainly attributed to soluble sCD26 [9] and serum levels of DPP4 activity and/or sCD26 protein were associated with diverse diseases including autoimmunity, infections, autoimmunity, and malignancies (reviewed in $[10,11])$. In vivo analyses in mice showed that serum sCD26/DPP4 originates from endothelial and bone marrow-derived cells [12]. It is generally accepted that sCD26/DPP4 
originates from the proteolytic cleavage of full length CD26/DPP4 and numerous proteases mediating the release of sCD26/DPP4 have been suggested. The matrix metalloproteases 1 (MMP1), MMP2, and MMP14 have been functionally associated with the shedding of sCD26/DPP4 from smooth muscle cells, while MMP9 has been implicated in the release of the soluble form from adipocytes [13] and MMP10/13 from ovarian cancer cells [14]. Apart from metalloproteases, the serine protease kallikrein 5 (KLK5) was suggested to facilitate sCD26/DPP4 release from $\mathrm{TH}_{17}$ cells [15].

Taken together, there are likely differentially regulated, cell-type specific mechanisms of (s)CD26/DPP4 release that are even more complex when considering potential interrelationships with other protease systems.

\section{Intracellular CD26/DPP4}

Of note, CD26/DPP4 is mainly located on the cell surface but based on the observation that both $\mathrm{CD}_{26^{+}}$and CD26 ${ }^{-}$T cells exhibit comparable levels of CD26/DPP4 mRNA and overall protein, an intracellular pool of CD26/DPP4 in T cells was suggested [16]. Furthermore, CD26/DPP4 was also detected in lysosomal organelles of hepatocytes, endothelial cells, and Kupffer cells in rat liver sections [17] and in secretory granules of A-cells in pig pancreatic islets by immunoelectron microscopy [18]. Moreover, CD26/DPP4 was identified in proteomic screens of enriched organelles from the leukemia/lymphoma NK cell line YTS [19] and of lysosomal effector compartments from non-transformed human T cells [20,21]. Additional analyses confirmed the intracellular storage of CD26/DPP4 in secretory granules of human cytotoxic lymphocytes including CD ${ }^{+} \alpha / \beta \mathrm{T}$ cells, $\gamma / \delta \mathrm{T}$ cells, and NK cells, and also in a small fraction of cytotoxic CD4 ${ }^{+} \alpha / \beta$ T cells, where it co-localizes with effector proteins like granzymes, perforin, and granulysin. Figure $2 \mathrm{~A}$ exemplarily shows the colocalization of intracellular CD26/DPP4 with the lysosomal and degranulation marker protein CD107a in $\mathrm{CD}^{+} / \mathrm{TCR} \alpha / \beta^{+}, \mathrm{CD}^{+} / \mathrm{TCR} \alpha / \beta^{+}, \mathrm{CD}^{+} / \mathrm{TCR}$ $\gamma / \delta^{+}$, and $\mathrm{CD}^{-} / \mathrm{CD} 56^{+}$cells and Figure $2 \mathrm{~B}$ with the cytotoxic effector proteins granzyme A, granzyme B, perforin, and granulysin in $\mathrm{CD}^{+} / \mathrm{TCR} \gamma / \delta^{+}$cells.

A

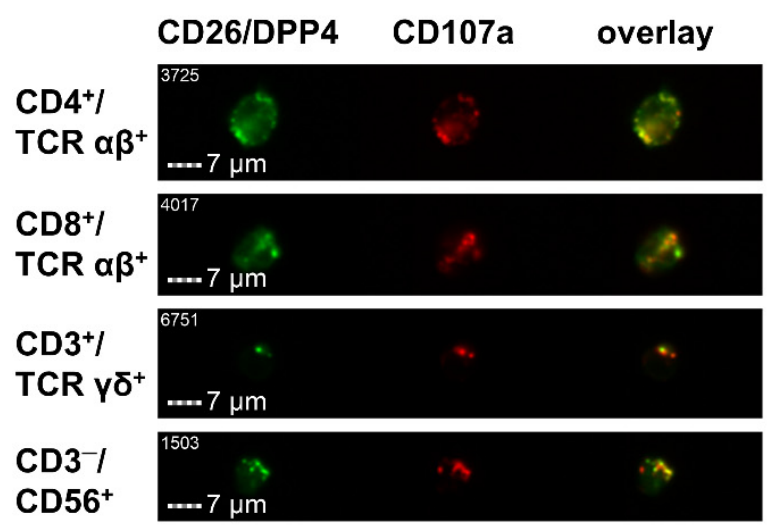

B

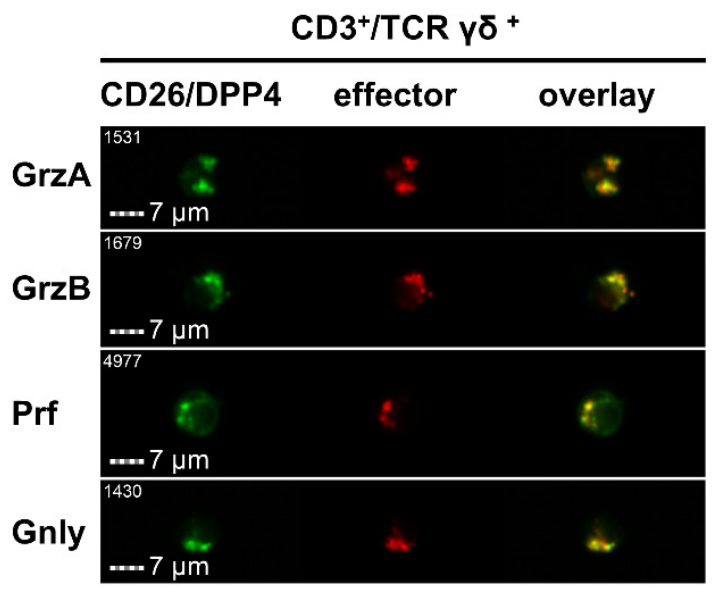

Figure 2. Intracellular storage of CD26 in cytotoxic effector lymphocytes. Co-localization of intracellular CD26 with (A) the lysosomal and degranulation marker protein CD107a (Lamp-1) in CD4 ${ }^{+} / \mathrm{TCR} \alpha \beta^{+}, \mathrm{CD}^{+} / \mathrm{TCR} \alpha \beta^{+}, \mathrm{CD}^{+} / \mathrm{TCR} \gamma \delta^{+}$, and $\mathrm{CD}^{-} / \mathrm{CD}^{+} 6^{+}$cells and (B) the cytotoxic effector proteins granzyme A (GrzA), granzyme B (GrzB), perforin (Prf), and granulysin (Gnly) in $\mathrm{CD}^{+} / \mathrm{TCR} \gamma \delta^{+}$cells.

In response to appropriate stimuli, intracellular CD26/DPP4 is rapidly translocated to the cell surface and this activation-induced degranulation is accompanied by the release of proteolytically active sCD26/DPP4. Effector lymphocytes are thus clearly an additional source of sCD26/DPP4 [22,23]. Moreover, these results might provide additional insight into disease-associated alterations of sCD26/DPP4 serum levels and indicate 
a so far unknown role of CD26/DPP4 in T cell-mediated cytotoxicity. In addition, full length CD26/DPP4 might be released in association with extracellular vesicles (EV). Here, CD26/DPP4 was detected on plasma exosomes of head and neck squamous carcinoma patients that were derived from both tumor cells and T cells [24]. Of note, in this scenario full-length CD26/DPP4 might ligate potential interaction partners in an autocrine and also paracrine manner. In addition, EV-released CD26/DPP4 is considered proteolytically active [25]. As an example, exosomes isolated from the plasma of acute myeloid leukemia (AML) patients inhibited colony formation of normal hematopoietic progenitor cells and were thus implicated in the suppression of hematopoiesis and to contribute to AML-associated cytopenia. These exosomes were characterized by the expression of enzymatically active CD26/DPP4 and DPP4 inhibition abrogated the effects on HPC colony formation [25]. However, in most contexts the functional role of EV-associated CD26/DPP4 is poorly characterized.

The sorting mechanisms that target CD26 to intracellular storage granules and to exosomes have not been analyzed so far. However, T-cell granules have been referred to as secretory lysosomes, bifunctional organelles that serve both as a degradative and a storage compartment that allows for regulated mobilization and fusion with the plasma membrane in response to appropriate stimuli. Transmembrane components are thus locally exposed on the cell surface while soluble effector molecules are secreted into the immunological synapse that is formed between target and effector cell [26,27]. As multivesicular bodies, these effector compartments contain intraluminal vesicles (ILV) that are released upon fusion with the plasma membrane and are then referred to as exosomes [28]. Since T-cell degranulation leads to an increase of CD26 surface expression [22], CD26 is likely located in the outer membrane of the effector granules and since it is also released as a transmembrane component of exosomes it must be additionally sorted to ILVs. The subcellular site of the proteolytic conversion of transmembrane CD26 to its soluble form is not known. Shedding of CD26 might either take place on the cell surface or within intracellular storage granules and precede degranulation to readily release the soluble form upon activation. The sorting mechanisms that target CD26 first to intracellular storage granules and subsequently to exosomes have not been characterized so far. Protein sorting to the lumen of MVB, the outer membrane, or subsequently to ILV relies on multiple different mechanisms. For example, granzymes and lysosomal hydrolases are targeted to effector granules via the mannose-6phosphate (M6P) pathway [29]. Here, a M6P tag is added to N-linked oligosaccharides in the cis-Golgi network (CGN). This tag is then recognized by transmembrane M6P receptors in the trans-Golgi network that bind to cargo proteins on the luminal side of the membrane and to adaptins in forming clathrin coats on the cytosolic side to allow for packaging into transport vesicles for the delivery to lysosomes (reviewed in [30]). Interestingly, in activated T cells CD26 is phosphorylated at mannose residues in its extracellular part and interacts with the M6P receptor although this was functionally associated with endocytosis rather than direct lysosomal trafficking from the trans-Golgi network (TGN) [31].

Like supposed for CD26, the transmembrane death factor FasL is also associated with the outer membrane of secretory lysosomes to end up on the cell surface after fusion with the plasma membrane as well as with the membrane of intraluminal vesicles to be released in association with exosomes [32,33]. The sorting of FasL is quite complex and involves SH3 domain-mediated binding of tyrosine kinases and proteins of the pombe/cdc15 homology family to an intracellular proline-rich domain and tyrosine phosphorylation at phosphorylation sites within the cytoplasmic tail [32,34-37]. Further sorting to intraluminal vesicles requires mono-ubiquitination at an intracellular KKR motif and the ESCRT machinery [32]. However, the sorting of other exosomal proteins does not rely on ESCRT proteins and involves different post-translational modifications (PTM) like SUMOylation, acetylation, or glycosylation (reviewed in [38]). Of note, the cytoplasmic tail of CD26 comprises only six amino acids (MKTPWK) and characteristic PTM have not been described so far. 


\section{Functions of CD26/DPP4}

\subsection{General Functions}

Considered a multifunctional "moonlighting" protein, the serine protease CD26/DPP4 has been implicated in numerous biological processes [39]. CD26/DPP4 effects are either dependent or independent of its enzymatic activity and are exerted by the transmembrane protein and/or the soluble form. CD26/DPP4 cleaves off N-terminal dipeptides with penultimate prolines or alanines and CD26/DPP4 substrates include gastrointestinal hormones, growth factors, chemokines, neuropeptides, and regulatory peptides including neuropeptide Y (NYP), glucose-dependent insulinotropic polypeptide (GIP), glucagon-like peptide 1/2 (GLP-1/2), stromal cell-derived factor-1 $\alpha$ (SDF-1 $\alpha$, CXCL12), CCL11/eotaxin1 , erythropoietin, granulocyte macrophage colony-stimulating factor (GM-CSF), CXCL10, and CCL5/RANTES (regulated upon activation normal T cell expressed and secreted). Here, the functional effects of CD26/DPP4-mediated cleavage include the inactivation of substrates, the modulation of receptor specificities or the generation of bioactive peptides (reviewed in [2]).

\subsection{Interaction Partners and Implications for T-Cell Function}

Interaction partners of CD26/DPP4 include for example adenosine deaminase [40], caveolin-1 [41], CD45 [42,43], CXCR4 [44], collagen (especially 1 and 3, [45]), fibronectin [46], glypican 3 [47], caspase-recruitment domain containing protein 1 (CARMA1, [48]) and $\mathrm{M} 6 \mathrm{P} / \mathrm{IgFr} 2([31,49])$ (for additional interaction partners refer to [1]). Moreover, CD26/DPP4 was also suggested as a (co-)receptor for SARS-CoV-2, the virus causing the respiratory syndrome COVID-19 [50] since the closely related virus MERS-CoV utilizes CD26/DPP4 for viral entry [51].

As a T cell surface molecule, CD26/DPP4 has been functionally associated with the modulation of T-cell activation and proliferation [52]. Early reports demonstrated that antibody-mediated ligation of CD26/DPP4 induced tyrosine phosphorylation of signaling molecules such as c-Cbl, MAP kinase, ERK1/2, Zap70, Lck, and CD3 [ [53]. However, despite recent advances the molecular details of the impact of CD26/DPP4 on T-cell activation and associated functional consequences for $\mathrm{T}$ cell-mediated immune responses are still far from being understood.

\subsubsection{Adenosine Deaminase}

As mentioned, CD26/DPP4 was shown to interact with ADA [40]. ADA is a $41 \mathrm{kDa}$ protein that catalyzes the conversion of adenosine and $2^{\prime}$-desoxyadenosine to inosine and $2^{\prime}$-desoxyinosine by deamination. ADA deficiency causes early-onset severe combined immunodeficiency (SCID), which is characterized by the loss of functional T, B, and NK cells, impaired cellular and humoral immunity, and susceptibility to infections [54]. Extracellular adenosine interferes with TCR signaling by binding to the adenosine receptor $2 \mathrm{a}$ (A2aR) expressed on effector T cells [55]. CD26/DPP4 was identified as an ADA-anchoring protein and in this way CD26/DPP4 accumulates ADA at the cell surface. ADA then metabolizes immunosuppressive adenosine and thus positively modulates T-cell activation (Figure 3) [56].

Depending on its binding to cell surface CD26/DPP4, ADA enhances the differentiation of naïve T cells to effector, memory, and regulatory T cells [57]. Moreover, within the immunological synapse formed between dendritic cells and T cells, ADA interactions with A1R and A2bR (DC side) and CD26/DPP4 (T-cell side) mediate costimulatory signals and promote T-cell proliferation and differentiation [58]. ADA-associated co-stimulation also facilitates an increase in Thelper type (Th) 1 cells and pro-inflammatory cytokines including interferon- $\gamma$ (IFN- $\gamma$ ), interleukin-6 (IL-6), and tumor necrosis factor- $\alpha$ (TNF- $\alpha$ ) [58]. Moreover, ADA treatment of CD26 $/ \mathrm{TCR} V \delta 2^{+} \mathrm{T}$ cells increased cytokine responsiveness and IFN- $\gamma$ production [59]. However, studies employing mutant CD26/DPP4 that is unable to bind ADA or that is catalytically inactive indicate that CD26/DPP4 modulates T-cell proliferation independent of ADA binding and substrate cleavage [60]. 


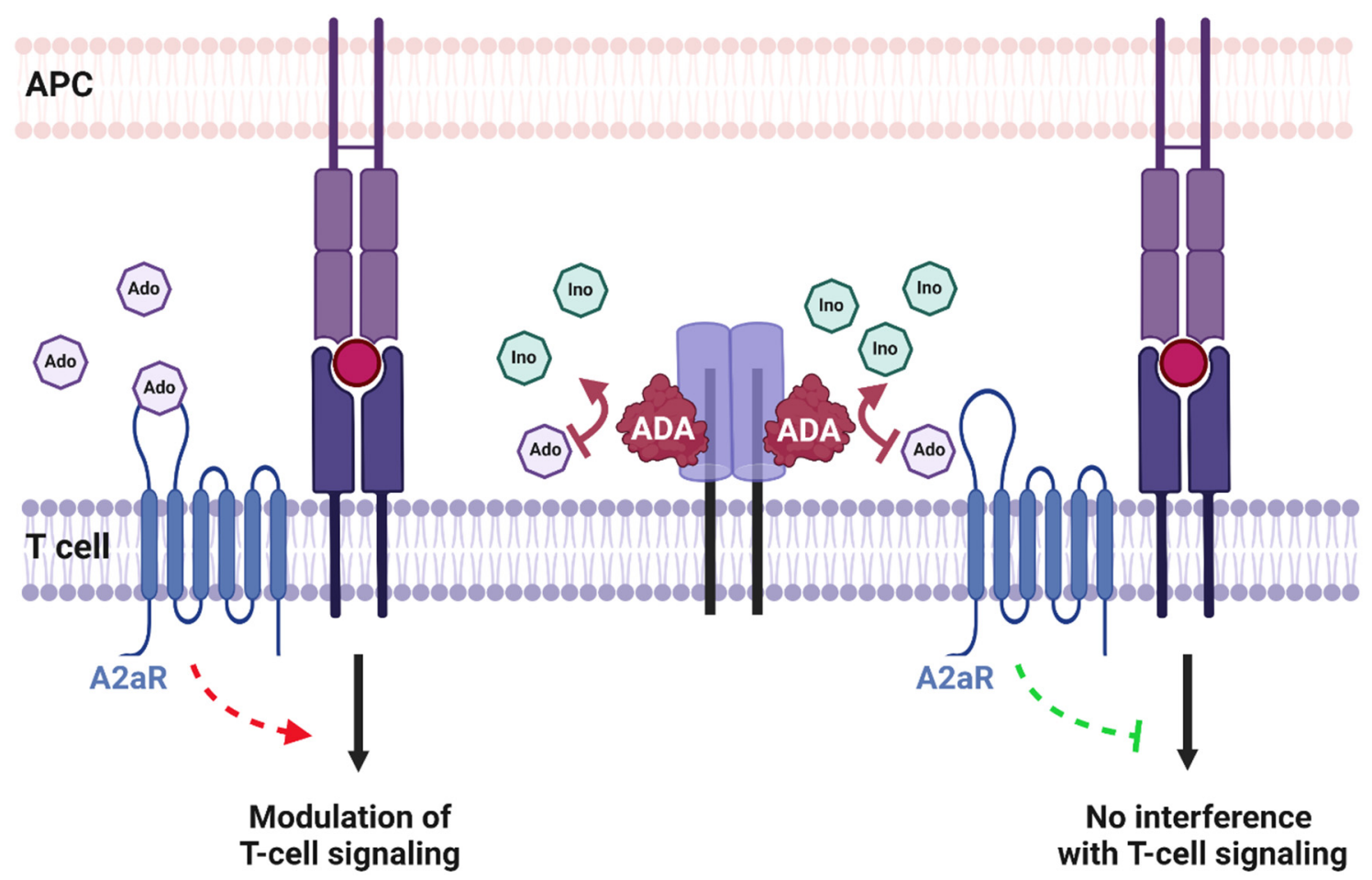

Figure 3. Interaction of CD26 with adenosine deaminase (ADA). Extracellular adenosine (Ado) interferes with T-cell receptor signaling by binding to the adenosine receptor $2 a(A 2 a R)$ expressed on $T$ cells (A). ADA anchored to CD26 metabolizes immunosuppressive adenosine to inosine (Ino) and in this way facilitates T-cell activation and differentiation to effector/memory T cells.

\subsection{2. $\mathrm{CD} 45$}

CD26/DPP4 also interacts with the cytoplasmic region of the tyrosine phosphatase CD45 to enhance T-cell receptor signaling. Antibody-induced ligation of CD26/DPP4 on $\mathrm{T}$ cells resulted in an internalization of CD26/DPP4, a decrease in CD45RO surface expression, increased Lck kinase activity, and enhanced phosphorylation of the CD3 chains $[42,43]$. Subsequent studies revealed that ligation of CD26/DPP4 triggers the recruitment of CD26/DPP4 molecules to rafts where it colocalizes with CD45 as a prerequisite for CD26/DPP4-modulated tyrosine phosphorylation [42].

\subsubsection{Caveolin-1}

T-cell CD26/DPP4 interacts with caveolin-1 on antigen-presenting cells and induces an increase in CD86 expression to facilitate T-cell co-stimulation [41]. In addition, CD26/DPP4 ligation by caveolin-1 enhances T-cell proliferation and NF- $\mathrm{KB}$ activation in a TCR/CD3dependent manner and is associated with the recruitment of a complex consisting of CD26/DPP4, CARMA1, Bcl10, and IKB kinase to lipid rafts (Figure 4) [5].

Interfering with the Caveolin-1/CD26 interaction with a soluble caveolin-1-Ig fusion protein induces anergy in $\mathrm{CD}^{+} \mathrm{T}$ cells [48]. In addition, CD26/DPP4-mediated co-stimulation of anti-CD3-activated $\mathrm{CD}^{+} \mathrm{T}$ cells enhances the cytotoxic properties compared to CD28-stimulated T cells and leads to increased expression of TNF- $\alpha$, IFN- $\gamma$, granzyme B (GrzB), and soluble Fas ligand (FasL) [61]. 


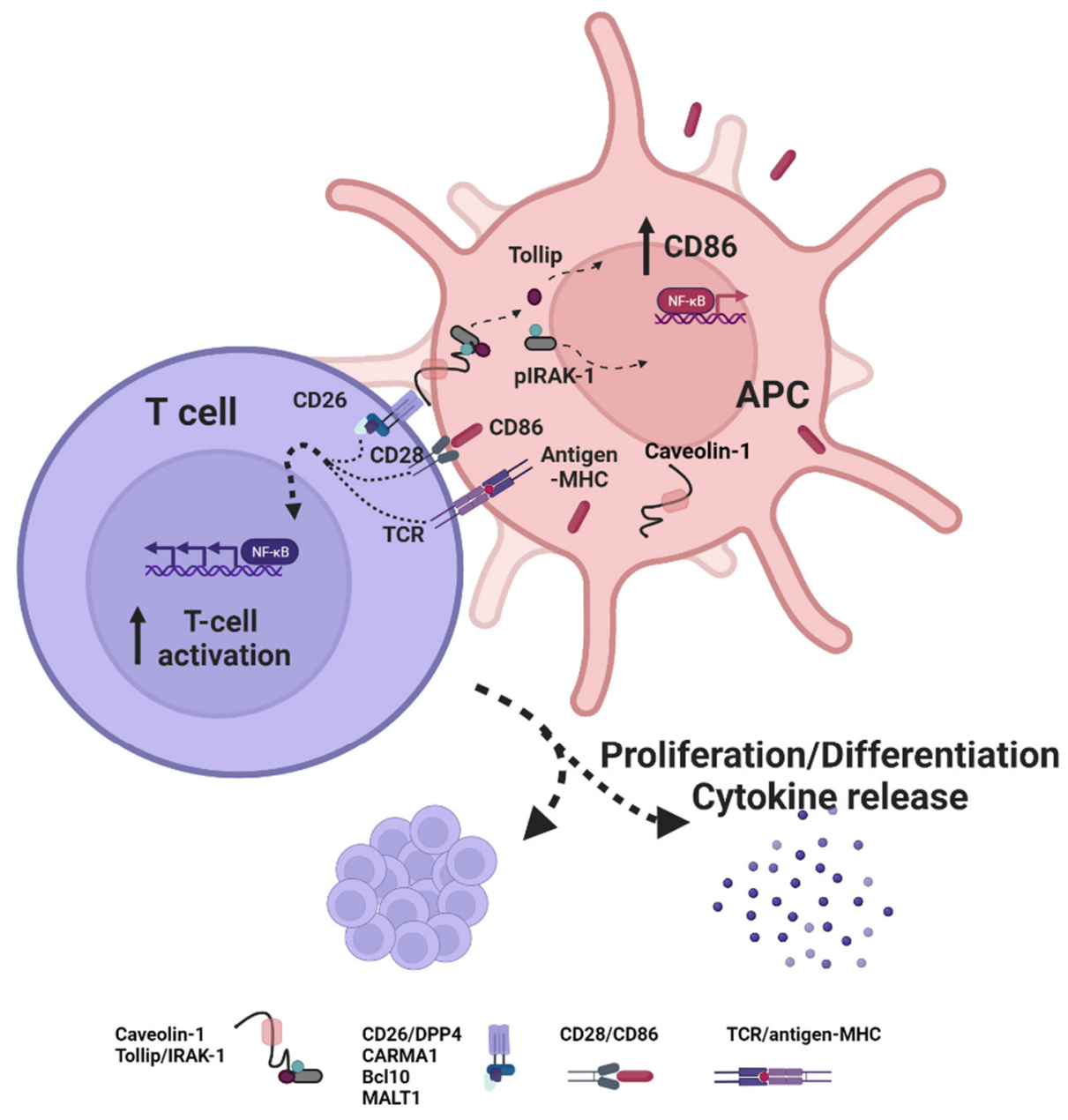

Figure 4. Interaction of CD26 with caveolin-1. Caveolin-1 on the surface of antigen-presenting cells (APC) binds to CD26 on the T-cell surface. This interaction induces an increase of the expression of the costimulatory ligand CD86 on APC thus enhancing T-cell co-stimulation by binding to CD28. In addition, caveolin-1-mediated CD26 ligation results in the recruitment of a complex composed of CD26, CARMA1, Bcl10, and MALT1 to lipid rafts and subsequent NF- KB activation in a TCR/CD3dependent manner. CD26-mediated co-stimulation enhances the T-cell proliferation and effector function with respect to cytotoxic properties and cytokine release.

\subsection{Effect of DPP4 Inhibitors on T-Cell Function}

Interestingly, DPP4 inhibitors including Sitagliptin, Teneligliptin, and Anagliptin that are used for the treatment of type 2 diabetes mellitus (T2DM, see below) were shown to have a negative impact on T-cell receptor signaling, T-cell activation, and proliferation in ex vivo analyses [62]. Moreover, in new-onset diabetic mice as an in vivo model system for autoimmunity DPP4 inhibition increased the proportion of T regulatory cells and even reversed the disease [63]. Altogether, this argues for an effect of CD26/DPP4 enzymatic activity on T-cell function. Of note, mice with genetic elimination of CD26/DPP4 or treated with DPP4 inhibitors nevertheless displayed robust primary and secondary antibody responses to T-dependent antigens, indicating that CD26/DPP4 might not be essentially required for mounting a T-cell directed immune response despite its proven role in T-cell activation [64]. However, available DPP4 inhibitors differ in their specificity for DPP4 and some also inhibit the closely related DPP8 and DPP9. In in vitro models of T-cell activation, highly selective DPP8/9 inhibitors attenuated T-cell proliferation and IL2-release while the specific inhibition of DPP4 did not affect T-cell activation indicating that previously observed immunological effects of several DPP4 inhibitor compounds may be due to off-target inhibition of DPP8/9 [65]. 


\subsection{CD26-Mediated Substrate Cleavage}

Thus, the exact role of CD26/DPP4 in T-cell dependent immune responses and the most probably differential impact of different CD26/DPP4-associated signaling pathways might be rather context-dependent and far more complex than initially anticipated. As mentioned, CD26/DPP4 substrates include a wide array of cytokines and chemokines that are either activated, inactivated, or modulated with respect to receptor specificity by CD26/DPP4-mediated cleavage [2]. Thus, the effect of CD26/DPP4 on chemokine/cytokine networks that potentially regulate T-cell function is remarkably complex.

\subsubsection{GIP/GLP-1}

As an example, CD26/DPP4 inactivates the insulinotropic incretin hormones GIP and GLP-1 by proteolysis. GIP and GLP-1 are released upon glucose intake and facilitate insulin secretion. The half-life of incretin hormones, however, is limited to only a few minutes due to CD26/DPP4-mediated cleavage. CD26/DPP4 inhibition prolongs the incretin effect and improves glucose tolerance. Commercially available CD26/DPP4 inhibitors are thus widely employed as an accompanying therapy in the treatment of diabetes mellitus type 2 [66]. Of note, blood glucose levels also affect T-cell activation, differentiation, and memory formation and glucose availability is locally limited at sites of infection/inflammation or in the tumor microenvironment (reviewed in $[67,68]$ ). For instance, in virus-specific T cells, reduced glucose levels in vitro significantly reduced cytokine production and cytotoxic effector potential but increased expression of CD69 and CD103 that are functionally linked to tissue retention $[23,69]$. Recent in vivo data suggested that sCD26/DPP4 secreted by bone marrow-derived cells might not contribute to systemic glucose control and affects plasma levels of GIP only and not of GLP-1/2 [12]. However, the effect of CD26/DPP4deficiency or inhibition in hematopoietic cells on the regulation of blood glucose levels during an immune response to infections as well as in the context of autoimmunity or T-cell activating or chimeric antigen receptor (CAR) T-cell-based immunotherapies of cancer malignancies has not been addressed yet.

\subsubsection{Chemokines}

CD26/DPP4 also cleaves several chemokines including for example CXCL12 (SDF-1 $\alpha$ ), CXCL10, CCL5/RANTES, and CCL11/eotaxin-1 (additional substrates reviewed in [2]). CXCL12 is a chemoattractant for lymphocytes, monocytes, and CD34 ${ }^{+}$hematopoietic precursor cells that express receptor CXCR4 [70]. CD26/DPP4-mediated removal of the two N-terminal amino acids converts full-length CXCL12 (1-67) to truncated CXCL12 (3-67) and completely revokes its chemotactic properties [71]. CXCL12 (3-67) retains significant binding affinity for the receptor and thus antagonizes the binding of biologically active CXCL12 (1-67) [72]. Likewise, CD26/DPP4-mediated processing of CXCL10 results in the generation of an antagonist form of the chemokine that inhibits T-cell and NK cell migration. The in vivo inhibition of CD26/DPP4 in humans can thus preserve the bioactive form of CXCL10. Here, DPP4 inhibitors might be employed as therapeutic immune modulators that affect T- and NK cell trafficking [73]. Likewise, CD26/DPP4 processes CCL5 that is released by activated T cells. In its full-length form, CCL5 (1-68) recruits innate immune cells to the site of inflammation whereas its chemotactic properties are drastically reduced upon CD26/DPP4-mediated conversion to CCL5 (3-68) [74]. Of note, the CD26-mediated cleavage of CCL5 might also enhance T-cell migration in certain scenarios [75]. For additional information on the role of CD26-mediated processing of chemokines in malignancies we recommend the recent in-depth review by De Zutter and colleagues [76].

\subsubsection{HMGB1}

High mobility group box 1 protein (HMGB1) is a ubiquitously expressed cytokine that is released upon injury and infection and functions as an alarmin to evoke inflammatory and regenerative responses. It modulates tissue regeneration, angiogenesis [77], and 
induces pro-inflammatory effects for example upon release from macrophages [78,79]. Furthermore, the release of HMGB1 from NK cells was shown to facilitate dendritic cell activation [80] and chemotaxis [81]. In breast cancer patients, HMGB1 released from dying tumor cells facilitates the anti-tumor immune response by ligation of Toll-like receptors 2 and 4 on dendritic cells to enhance processing and presentation of tumor antigens [82]. In addition, NK cell-derived HMGB1 also induces a distinct form of necrotic cell death in cancer cells that targets mitochondrial energy metabolism by blocking pyruvate kinase isoform M2 thus inhibiting glucose-dependent aerobic respiration ultimately killing cancer cells by restricting their energy supply to glycolysis $[83,84]$. Interestingly, HMGB1 was also shown to have intrinsic antimicrobial activity [85]. Given its alarmin functions as well as its immunomodulatory and direct cytotoxic effector properties, HMGB1 subcellular location, release, and activity is regulated on several levels [86]. Interestingly, CD26/DPP4 cleaves HMGB1 at its N-terminal region and modulates HMGB1 function. As an example, CD26/DPP4-mediated HMGB1 processing inhibited HMGB1-induced endothelial cell migration. Moreover, this truncated form of HMGB1 was also detected in the serum of T2DM patients and the application of DPP4 inhibitors enhanced levels of full-length HMGB1 [87]. However, the effects of CD26/DPP4-mediated HMGB1 processing on its anti-bacterial and anti-tumor effects and its regulated release have not been analyzed so far.

Taken together, the impact of CD26/DPP4-mediated substrate processing on immune cells is quite complex with diverse functional outcomes. However, especially the role of lymphocyte-derived sCD26/DPP4 at the sites of immune cell activation and effector function on the processing of its substrates and associated functional consequences yet remain to be addressed.

\subsection{CD26 as a T-Cell Marker Protein}

Despite these open questions with respect to involved signaling pathways, CD26/DPP4 expression was clearly correlated with T-cell function, thus making it an interesting marker protein. It has been noted that increased CD26/DPP4 expression on CD4 ${ }^{+} \mathrm{T}$ cells correlates with a $\mathrm{TH}_{1}$-like phenotype whereas lower CD26/DPP4 expression was mainly seen on $\mathrm{TH}_{2}$-like $\mathrm{CD} 4^{+} \mathrm{T}$ cells [88]. After anti-CD3 antibody-mediated in vitro expansion, CD26 ${ }^{+} \mathrm{T}$ cells were shown to express higher levels of IL-2, IFN- $\gamma$, IL-6, IL17, IL-22, IL-23 receptor (IL-23R), CCR6 and CD161 compared to CD26 ${ }^{\text {low }}$ cells [89]. Among human peripheral blood mononuclear cells (PBMCs), CD26 hi $/ \mathrm{CD}^{+} \mathrm{T}$ cells are mainly CD26 $6^{\text {hi }} / \mathrm{CD}_{2} 8^{+} / \mathrm{CCR}^{-} / \mathrm{CD}^{2} 5 \mathrm{RA}^{-}$effector memory cells [61]. Furthermore, high CD26/DPP4 expression along with low CD94 expression defines transcriptionally distinct TCR V $82^{+} \mathrm{T}$ cells. Exposure of CD26 6 hi $/$ D $94^{\text {low }} \mathrm{TCR} V \delta 2^{+} \mathrm{T}$ cells to phosphoantigen in the presence of IL-23 and simultaneous ligation of CD26/DPP4 with an agonistic antibody enhances the cytotoxic potential rendering them ideal targets for immunotherapeutic expansion and adoptive transfer [59]. In another analysis, the characterization of CD26- $1 \mathrm{ym}-$ phocyte subsets and those with an intermediate $\left(\mathrm{CD} 26^{\text {int }}\right)$ and high $\left(\mathrm{CD} 26^{\mathrm{hi}}\right) \mathrm{CD} 26 / \mathrm{DPP} 4$ expression revealed striking differences in anti-tumor properties. Here, CD26 ${ }^{\text {hi }} / \mathrm{CD} 4^{+} \mathrm{T}$ cells display a potent effector function against solid tumors. CD26 $6^{\mathrm{hi}} / \mathrm{CD} 4^{+} \mathrm{T}$ cells expressed high levels of cytotoxic effector molecules including Perforin, GrzA, GrzB, and GrzK and displayed an elevated expression of the chemokines MIP-1 $\beta$ (macrophage inflammatory protein-1 $\beta$ ) and RANTES and of the cytokines IFN- $\gamma$, TNF- $\alpha$, IL-2, IL-17, and IL-22 with a high fraction of cells co-secreting $4-5$ cytokines simultaneously $[90,91]$. Of note, despite the expression of IL-17A, CD26 ${ }^{\text {hi }} / \mathrm{CD}^{+} \mathrm{T}$ cells seem to be epigenetically and transcriptionally distinct from $\mathrm{TH}_{17}$ cells [90]. In addition, $\mathrm{CD} 26^{\text {hi }} \mathrm{T}$ cells display a characteristic chemokine receptor profile (CXCR3, CCR6, CD161) and are characterized by profound cytotoxicity, resistance to apoptosis, and enhanced stemness [90,91]. In accordance with these findings, $\mathrm{CD} 26^{\mathrm{hi}} / \mathrm{CD} 4^{+} \mathrm{T}$ cells genetically engineered to express a CAR recognizing mesothelin, an antigen overexpressed in mesothelioma, displayed an outstanding capacity to traffic to, survive in, and regress solid tumors in NSG xenograft mesothelioma models. In this scenario, the anti-tumor response of CD26 ${ }^{\text {hi }} \mathrm{T}$ cells was superior to other CD4 T-cell subsets 
such as $\mathrm{TH}_{17}$ and bulk $\mathrm{CD} 4^{+} \mathrm{T}$ cells and did not require $\mathrm{CD} 8^{+} \mathrm{T}$ cells indicative of a direct tumor-lysing capacity [90]. Interestingly, preliminary data also indicate that treatment with the CD26/DPP4 inhibitor sitagliptin impaired the migration of CD26 ${ }^{\text {hi }}$ mesothelin-specific CAR T cells, thus limiting tumor infiltration by $\mathrm{CD} 26^{\mathrm{hi}} \mathrm{T}$ cells resulting in impaired tumor control. Of note, in this scenario sitagliptin did not impair the overall ability of $\mathrm{T}$ cells to respond to antigen [92]. Given these results, the monitoring and characterization of tumor-infiltrating $\mathrm{CD} 26^{+} \mathrm{T}$ cells at the onset and during immunotherapy might help to assess its value as a predictive marker. In the context of immune checkpoint blockade where the presence of tumor-specific $T$ cells is a prerequisite for an efficient response to therapy, patients who benefited from treatment displayed an increased proportion of CD26 ${ }^{\mathrm{hi}}$ tumor-infiltrating lymphocytes (TIL) prior to and following therapy [93]. Moreover, upon immune checkpoint blockade in mice, CD26/DPP4 is upregulated only in TIL from those animals that mounted an efficient anti-tumor response. However, more clinical studies are needed to address the role of CD26/DPP4 expression in TIL especially with respect to their role in the induction of effective immune responses and durable remissions following cancer immunotherapy and to unravel the underlying mechanisms in detail.

Of note, immunomodulatory effects also play a crucial role when considering the efficacy of $\mathrm{T}$ cell-based immunotherapies. Here, the blockade of the regulatory $\mathrm{T}$ cells (Tregs) is generally considered to be beneficial for the treatment outcome [94].

Recent analyses show that CD26 is present on FoxP3-expressing activated CD4 $4^{+}$effector T cells but absent from Tregs or expressed at reduced levels. Since this CD26 $6^{-/ \mathrm{low}}$ phenotype is stable it allows for the differentiation of Tregs from effector T cells in analyses or enrichment protocols [95]. This reduced expression or absence in Tregs might also partially account for their functional properties. Since cell surface CD26 binds ADA, reduced CD26 levels might increase levels of immunosuppressive adenosine and adenosine in turn has been shown to increase the numbers of Tregs and to further promote their immunoregulatory activity [96]. As already mentioned, the interaction of CD26 with caveolin-1 increases the expression of costimulatory CD86 molecules in APCs, whereas Tregs downmodulate both CD80 and CD86 expression via a CTLA4-dependent mechanism [97]. Of note, CD86 is upregulated in response to proinflammatory stimuli and preferentially binds to activating CD28, whereas CD80 appears to be rather specific for the inhibitory receptor CTLA-4 [98,99]. Therefore, in this scenario, the low expression of CD26 on Tregs might contribute to low levels of proinflammatory CD86 on APCs which results in insufficient activation of antigen-primed naïve T-cells ultimately inducing anergy.

\section{CD26/DPP4 in T-Cell Malignancies}

Given its diverse functions, it is not surprising that dysregulation of the expression or the enzymatic activity of CD26/DPP4 might contribute to cancer development [100].

Although we focus on T-cell malignancies in the following, it should be mentioned that several solid tumors including for example colorectal cancer (CRC), hepatocellular cancer (HCC), malignant mesothelioma and renal cell carcinoma (RCC) express CD26/DPP4. For instance, high expression levels of CD26/DPP4 were significantly associated with advanced tumor stages in a cohort of CRC patients and with reduced overall and disease-free survival [101]. Moreover, in preclinical model systems of RCC and malignant mesothelioma, the presence of blocking anti-CD26/DPP4 antibodies inhibited tumor growth and metastasis. Meanwhile, the humanized anti-CD26/DPP4 mAb YS110 (NCT03177668) has already been tested in humans for its safety and efficacy for the treatment of aggressive malignant mesothelioma, a disease with otherwise still very limited treatment options [102,103]. CD26 has also been functionally associated with metastasis. The escape of cancer cells from the primary tumor, entry into the blood stream, and extravasation to form new tumor colonies in secondary organs require the action of a wide variety of cytokines, chemokines, ligands, receptors, and many of those are either substrates or binding partners of CD26 [104,105]. However, some cancer types are characterized by a low expression of CD26, and studies even indicated that induced expression of CD26 in those malignant cells reverted the malig- 
nant phenotype and improved control of metastasis, invasion, and proliferation [106,107]. The functional role of CD26 in malignant cells appears to depend on tumor localization, cell type, and the local microenvironment and CD26 can be regarded as both a tumor suppressor and as a marker of tumor aggressiveness.

Early studies also suggested a role of CD26/DPP4 in hematological malignancies. CD26/DPP4 is expressed on aggressive T-cell hematological malignancies such as T-cell lymphoblastic lymphoma (T-LBL) and T-cell acute lymphoblastic leukemia (T-ALL) and was associated with poor survival [108]. At the functional level, antibody- or siRNAmediated inhibition of CD26/DPP4 in the CD26+ T-ALCL (anaplastic large cell lymphoma) line Karpas-299 resulted in decreased adhesion properties in vitro and improved survival in vivo [109].

As mentioned, pharmacologic inhibitors of CD26/DPP4 have been in clinical use for over a decade to improve glucose tolerance in diabetic patients [66]. While distinct reports indicate an increase in incidence rates of selected cancers [110-112], other studies argue against an association of tumor incidence and CD26/DPP4 inhibition and some analyses even indicate that CD26/DPP4 inhibition might instead improve outcomes related to certain tumor types [113-118]. However, current clinical evidence is not sufficient to evaluate potential tumor-promoting or tumor-suppressive effects of CD26/DPP4 inhibition and functional explanations are still missing. Here, especially effects of CD26/DPP4 inhibition on the immune system are discussed to potentially affect tumor incidence rather than direct pro-tumorigenic effects on healthy cells [1]. Apart from its potential role as a therapeutic target, levels of CD26/DPP4 expression and sCD26/DPP4 release are discussed as putative diagnostic and prognostic markers.

Although CD26/DPP4 surface expression in B-ALL, AML, and T-ALL was comparable to levels observed in patients with non-leukemic hematologic alterations or in healthy controls, plasma CD26/DPP4 activity was significantly higher in leukemia patients [119]. However, the diagnostic and prognostic value of (s)CD26/DPP4 in most hematologic malignancies is still a matter of debate. Nevertheless, numerous studies analyzed CD26/DPP4 cell surface expression and levels of sCD26/DPP4 in the serum of patients with cutaneous T-cell lymphoma (CTCL) including the most frequent CTCL mycosis fungoides (MF) and Sézary syndrome (SS) [120]. It has been noted that serum sCD26/DPP4 levels were significantly lower in patients with MF compared to healthy controls [121], and plasma CD26/DPP4 activity was decreased in patients with SS or MF compared to healthy individuals [120]. In addition, it has been reported that CD26/DPP4 expression predominates in the early stages of MF [122] and is lost with disease progression [121-124]. Likewise, frequencies of $\mathrm{CD}^{-} 6^{-} / \mathrm{CD}^{+} \mathrm{T}$ cells are significantly increased in SS [122]. This loss of CD26/DPP4 expression is also observed in the CD8 ${ }^{+}$T-cell compartment in both MF [125] and SS [126]. Counts of these atypical CD26- lymphoid cells referred to as Sézary cells are meanwhile considered a quite sensitive and specific parameter for the early detection of SS and of MF. Thus, CD26/DPP4 is meanwhile included in validated EuroFlow panels for the immunophenotyping of T-cell chronic lymphoproliferative diseases [127-131]. Although other markers can be overexpressed (e.g., PD-1) [132] or lost (e.g., CD7) [133] in CTCL, CD26/DPP4 is meanwhile one of the most established marker proteins for SS and MF markers $[130,131]$. The frequency of CD26 ${ }^{-} / \mathrm{CD}^{+} \mathrm{T}$ cells displays the extent of blood involvement and can be used for monitoring disease status, treatment response, and to assess prognosis [134] and is thus recommended for staging by the EORTC/ISCL (European Organization for Research and Treatment of Cancer/International Society for Cutaneous Lymphoma) and as a diagnostic criterion for SS syndrome [135]. However, it has been proposed recently to evaluate the degree of blood involvement based on absolute counts of atypical lymphocytes [136]. Of note, counts of $\mathrm{CD}^{2} 6^{-} / \mathrm{CD} 4^{+} \mathrm{T}$ cells are not sufficient for CTCL diagnosis since not all CTCLs display a loss of CD26/DPP4 (and CD7) expression. Moreover, loss of CD26/DPP4 expression might also be observed under physiological conditions or in non-malignant pathological conditions such as aging and rheumatoid arthritis [137]. In a patient with relapsed MF, malignant T cells with the same TCR as 
at initial diagnosis gained CD26/DPP4 expression indicative of evolution of the original malignant clone and highlighting that the loss of CD26/DPP4 expression is not a universal parameter for defining aberrant leukemic T cells in these diseases [138]. Thus, assessment of more clinicopathological features and the refinement of expression thresholds is required for the accurate identification and monitoring of aberrant T cells. Currently, a consortium of EuroFlow is working on the definition of a refined standardized flow cytometry panel assessing the expression of more than eight markers to diagnose SS patients with the highest possible sensitivity.

Of note, also the prognostic value of CD26/DPP4 expression is still a matter of debate. A recent study performed with large-cell transformed MF (a potentially more aggressive variant of MF) patients indicated that reduced CD26/DPP4 expression on $\mathrm{CD} 4^{+} \mathrm{T}$ cells might be associated with poor prognosis [139], whereas a retrospective cohort analysis of 11 patients with erythrodermic CTCL indicated that the frequency of $\mathrm{CD} 26^{-} / \mathrm{CD} 4^{+} \mathrm{T}$ cells was not a reliable marker of treatment response or disease progression [140]. Here, analyses of larger cohorts are needed to evaluate the prognostic value of CD26/DPP4 expression.

In addition, as already mentioned, CD26/DPP4 is stored in the cytotoxic granules in a fraction of cytotoxic $\mathrm{T}$ cells and NK cells [22] and its surface expression thus follows a more complex and activation-dependent regulation. However, most if not all studies evaluating the diagnostic or prognostic value of CD26/DPP4 expression were limited to analyses of CD26/DPP4 surface expression.

\section{Conclusions}

CD26/DPP4 is a multifunctional protein with a wide array of substrates and interaction partners. CD26/DPP4 effects are exerted by either the transmembrane protein and/or the soluble form and are dependent or independent of its enzymatic activity. CD26/DPP4mediated cleavage might result in the modulation of receptor specificities, the inactivation of substrates, or the generation of bioactive peptides. Full length CD26/DPP4 can be released in association with extracellular vesicles, while soluble CD26/DPP4 is shed from the cell surface by proteases. Moreover, CD26/DPP4 is stored in cytotoxic granules of lymphocytes from where it is released upon activation or target cell encounter. Thus, deciphering the precise role of CD26/DPP4 in different aspects of T-cell biology is a challenging task especially with respect to the complex regulation of cytokine/chemokine networks and the likely context-dependent and differential impact of different CD26/DPP4-associated signaling pathways.

Nevertheless, CD26/DPP4 has been clearly implicated in the modulation of T-cell activation, proliferation, and effector function and $\mathrm{CD} 26^{+} \mathrm{T}$ cells are characterized by remarkable anti-tumor properties with respect to cytotoxic and migratory properties. In cutaneous T-cell lymphoma, especially in Sézary syndrome and in mycosis fungoides, CD26/DPP4 expression patterns emerged as an established marker for diagnosis and treatment monitoring.

However, further studies are needed to understand the precise functional role of CD26/DPP4 in the anti-tumor response of T cells to further optimize T-cell based immunotherapies employing CAR T cells or adoptively transferred autologous $\mathrm{T}$ cells and to establish the infiltration of different tumor entities with $\mathrm{CD}_{2} 6^{+}$tumor-infiltrating lymphocytes as a prognostic factor. Likewise, further analyses employing larger patient cohorts might help to further refine the diagnostic value of CD26/DPP4 expression in cutaneous T-cell lymphoma and to assess its suitability as a prognostic factor.

Moreover, whereas some studies already suggest CD26/DPP4 as a therapeutic target in solid cancers, data regarding hematologic malignancies are still missing.

Author Contributions: Conceptualization, M.L.; writing-original draft preparation, G.C., U.W. and M.L.; writing-review and editing, G.C., U.W., M.B., O.J. and M.L.; visualization, G.C. and M.L.; funding acquisition, G.C., M.B. and O.J. All authors have read and agreed to the published version of the manuscript. 
Funding: This research was funded by Deutsche Krebshilfe, grant number 70113252 (to G.C., M.B.), Deutsche José Carreras Leukämie-Stiftung, grant number DJCLS 22R/2019 (to G.C., M.B., O.J.), the Deutsche Forschungsgemeinschaft, grant number JA 610/7-3 (to O.J.) and the "clinician scientist program in evolutionary medicine", grant number 413490537 (to M.B.).

Data Availability Statement: The data presented in this article are available on request from Marcus Lettau at marcus.lettau@uksh.de.

Acknowledgments: Illustrations were created with BioRender.com. The authors also thank Veit Becker for helpful assistance.

Conflicts of Interest: The authors declare no conflict of interest. The funders had no role in the design and the writing of the manuscript, or in the decision to publish it.

\section{References}

1. Klemann, C.; Wagner, L.; Stephan, M.; von Hörsten, S. Cut to the chase: A review of CD26/dipeptidyl peptidase-4's (DPP4) entanglement in the immune system. Clin. Exp. Immunol. 2016, 185, 1-21. [CrossRef]

2. Mulvihill, E.E.; Drucker, D.J. Pharmacology, Physiology, and Mechanisms of Action of Dipeptidyl Peptidase-4 Inhibitors. Endocr. Rev. 2014, 35, 992-1019. [CrossRef]

3. Ohnuma, K.; Dang, N.H.; Morimoto, C. Revisiting an old acquaintance: CD26 and its molecular mechanisms in T cell function. Trends Immunol. 2008, 29, 295-301. [CrossRef]

4. Chung, K.-M.; Cheng, J.-H.; Suen, C.-S.; Huang, C.-H.; Tsai, C.-H.; Huang, L.-H.; Chen, Y.-R.; Wang, A.H.-J.; Jiaang, W.-T.; Hwang, M.-J.; et al. The dimeric transmembrane domain of prolyl dipeptidase DPP-IV contributes to its quaternary structure and enzymatic activities. Protein Sci. 2010, 19, 1627-1638. [CrossRef]

5. Ohnuma, K.; Uchiyama, M.; Yamochi, T.; Nishibashi, K.; Hosono, O.; Takahashi, N.; Kina, S.; Tanaka, H.; Lin, X.; Dang, N.H.; et al. Caveolin-1 Triggers T-cell Activation via CD26 in Association with CARMA1. J. Biol. Chem. 2007, 282, 10117-10131. [CrossRef]

6. Abbott, C.A.; Baker, E.; Sutherland, G.R.; Mccaughan, G.W. Genomic organization, exact localization, and tissue expression of the human CD26 (dipeptidyl peptidase IV) gene. Immunogenetics 1994, 40, 331-338. [CrossRef]

7. Hong, W.; Petell, J.K.; Swank, D.; Sanford, J.; Hixson, D.C.; Doyle, D. Expression of dipeptidyl peptidase IV in rat tissues is mainly regulated at the mRNA levels. Exp. Cell Res. 1989, 182, 256-266. [CrossRef]

8. Dinjens, W.N.; Ten Kate, J.; Wijnen, J.T.; van der Linden, E.P.; Beek, C.J.; Lenders, M.H.; Khan, P.M.; Bosman, F.T. Distribution of adenosine deaminase-complexing protein in murine tissues. J. Biol. Chem. 1989, 32, 19215-19220. [CrossRef]

9. Durinx, C.; Lambeir, A.-M.; Bosmans, E.; Falmagne, J.-B.; Berghmans, R.; Haemers, A.; Scharpé, S.; De Meester, I. Molecular characterization of dipeptidyl peptidase activity in serum. JBIC J. Biol. Inorg. Chem. 2000, 267, 5608-5613. [CrossRef]

10. Cordero, Ó.J.; Salgado, F.J.; Nogueira, M. On the origin of serum CD26 and its altered concentration in cancer patients. Cancer Immunol. Immunother. 2009, 58, 1723-1747. [CrossRef]

11. Yazbeck, R.; Jaenisch, S.E.; Abbott, C.A. Potential disease biomarkers: Dipeptidyl peptidase 4 and fibroblast activation protein. Protoplasma 2017, 255, 375-386. [CrossRef]

12. Mulvihill, E.E.; Varin, E.M.; Gladanac, B.; Campbell, J.E.; Ussher, J.R.; Baggio, L.L.; Yusta, B.; Ayala, J.; Burmeister, M.A.; Matthews, D.; et al. Cellular Sites and Mechanisms Linking Reduction of Dipeptidyl Peptidase-4 Activity to Control of Incretin Hormone Action and Glucose Homeostasis. Cell Metab. 2017, 25, 152-165. [CrossRef]

13. Röhrborn, D.; Eckel, J.; Sell, H. Shedding of dipeptidyl peptidase 4 is mediated by metalloproteases and up-regulated by hypoxia in human adipocytes and smooth muscle cells. FEBS Lett. 2014, 588, 3870-3877. [CrossRef]

14. Moffitt, L.R.; Bilandzic, M.; Wilson, A.L.; Chen, Y.; Gorrell, M.D.; Oehler, M.K.; Plebanski, M.; Stephens, A.N. Hypoxia Regulates DPP4 Expression, Proteolytic Inactivation, and Shedding from Ovarian Cancer Cells. Int. J. Mol. Sci. 2020, 21, 8110. [CrossRef]

15. Nargis, T.; Kumar, K.; Ghosh, A.R.; Sharma, A.; Rudra, D.; Sen, D.; Chakrabarti, S.; Mukhopadhyay, S.; Ganguly, D.; Chakrabarti, P. KLK5 induces shedding of DPP4 from circulatory Th17 cells in type 2 diabetes. Mol. Metab. 2017, 6, 1529-1539. [CrossRef]

16. Mattern, T.; Reich, C.; Duchrow, M.; Ansorge, S.; Ulmer, A.J.; Flad, H.D. Antibody-induced modulation of CD26 surface expression. Immunology 1995, 84, 595-600.

17. Fukui, Y.; Yamamoto, A.; Kyoden, T.; Kato, K.; Tashiro, Y. Quantitative immunogold localization of dipeptidyl peptidase IV(DPP IV) in rat liver cells. Cell Struct. Funct. 1990, 15, 117-125. [CrossRef]

18. Poulsen, M.D.; Hansen, G.H.; Dabelsteen, E.; Høyer, P.E.; Norén, O.; Sjöström, H. Dipeptidyl peptidase IV is sorted to the secretory granules in pancreatic islet A-cells. J. Histochem. Cytochem. 1993, 41, 81-88. [CrossRef]

19. Casey, T.M.; Meade, J.L.; Hewitt, E.W. Organelle Proteomics. Mol. Cell. Proteom. 2007, 6, 767-780. [CrossRef]

20. Schmidt, H.; Gelhaus, C.; Nebendahl, M.; Lettau, M.; Lucius, R.; Leippe, M.; Kabelitz, D.; Janssen, O. Effector granules in human T lymphocytes: The luminal proteome of secretory lysosomes from human T cells. Cell Commun. Signal. 2011, 9, 4. [CrossRef]

21. Schmidt, H.; Gelhaus, C.; Nebendahl, M.; Lettau, M.; Lucius, R.; Leippe, M.; Kabelitz, D.; Janssen, O. Effector Granules in Human T Lymphocytes: Proteomic Evidence for Two Distinct Species of Cytotoxic Effector Vesicles. J. Proteome Res. 2011, 10, 1603-1620. [CrossRef] [PubMed] 
22. Lettau, M.; Dietz, M.; Vollmers, S.; Armbrust, F.; Peters, C.; Dang, T.M.; Chitadze, G.; Kabelitz, D.; Janssen, O. Degranulation of human cytotoxic lymphocytes is a major source of proteolytically active soluble CD26/DPP4. Cell. Mol. Life Sci. 2019, 77, 751-764. [CrossRef]

23. Casrouge, A.; Sauer, A.V.; da Silva, R.B.; Tejera-Alhambra, M.; Sánchez-Ramón, S.; Cancrini, C.; Ingersoll, M.A.; Aiuti, A.; Albert, M.L. Lymphocytes are a major source of circulating soluble dipeptidyl peptidase 4. Clin. Exp. Immunol. 2018, 194, 166-179. [CrossRef]

24. Theodoraki, M.-N.; Hoffmann, T.K.; Jackson, E.K.; Whiteside, T.L. Exosomes in HNSCC plasma as surrogate markers of tumour progression and immune competence. Clin. Exp. Immunol. 2018, 194, 67-78. [CrossRef]

25. Namburi, S.; Broxmeyer, H.E.; Hong, C.-S.; Whiteside, T.L.; Boyiadzis, M. DPP4+ exosomes in AML patients' plasma suppress proliferation of hematopoietic progenitor cells. Leukemia 2021, 7, 1925-1932. [CrossRef]

26. Lettau, M.; Kabelitz, D.; Janssen, O. Lysosome-Related Effector Vesicles in T Lymphocytes and NK Cells. Scand. J. Immunol. 2015, 82, 235-243. [CrossRef]

27. Stinchcombe, J.; Bossi, G.; Griffiths, G.M. Linking Albinism and Immunity: The Secrets of Secretory Lysosomes. Science 2004, 305, 55-59. [CrossRef]

28. Zhang, Y.; Liu, Y.; Liu, H.; Tang, W.H. Exosomes: Biogenesis, biologic function and clinical potential. Cell Biosci. 2019, 9, 19. [CrossRef]

29. Griffiths, G.M.; Isaaz, S. Granzymes A and B are targeted to the lytic granules of lymphocytes by the mannose-6-phosphate receptor. J. Cell Biol. 1993, 120, 885-896. [CrossRef]

30. Coutinho, M.F.; Prata, M.J.; Alves, S. Mannose-6-phosphate pathway: A review on its role in lysosomal function and dysfunction. Mol. Genet. Metab. 2012, 105, 542-550. [CrossRef]

31. Ikushima, H.; Munakata, Y.; Ishii, T.; Iwata, S.; Terashima, M.; Tanaka, H.; Schlossman, S.F.; Morimoto, C. Internalization of CD26 by mannose 6-phosphate/insulin-like growth factor II receptor contributes to T cell activation. Proc. Natl. Acad. Sci. USA 2000, 97, 8439-8444. [CrossRef] [PubMed]

32. Zuccato, E.; Blott, E.J.; Holt, O.; Sigismund, S.; Shaw, M.; Bossi, G.; Griffiths, G.M. Sorting of Fas ligand to secretory lysosomes is regulated by mono-ubiquitylation and phosphorylation. J. Cell Sci. 2007, 120, 191-199. [CrossRef]

33. Lettau, M.; Qian, J.; Linkermann, A.; Latreille, M.; Larose, L.; Kabelitz, D.; Janssen, O. The adaptor protein Nck interacts with Fas ligand: Guiding the death factor to the cytotoxic immunological synapse. Proc. Natl. Acad. Sci. USA 2006, 103, 5911-5916. [CrossRef]

34. Baum, W.; Kirkin, V.; Fernández, S.B.M.; Pick, R.; Lettau, M.; Janssen, O.; Zörnig, M. Binding of the Intracellular Fas Ligand (FasL) Domain to the Adaptor Protein PSTPIP Results in a Cytoplasmic Localization of FasL. J. Biol. Chem. 2005, 280, 40012-40024. [CrossRef] [PubMed]

35. Qian, J.; Chen, W.; Lettau, M.; Podda, G.; Zörnig, M.; Kabelitz, D.; Janssen, O. Regulation of FasL expression: A SH3 domain containing protein family involved in the lysosomal association of FasL. Cell. Signal. 2006, 18, 1327-1337. [CrossRef]

36. Voss, M.; Lettau, M.; Paulsen, M.; Janssen, O. Posttranslational regulation of Fas ligand function. Cell Commun. Signal. 2008, 6, 11. [CrossRef]

37. Wenzel, J.; Sanzenbacher, R.; Ghadimi, M.; Lewitzky, M.; Zhou, Q.; Kaplan, D.R.; Kabelitz, D.; Feller, S.M.; Janssen, O. Multiple interactions of the cytosolic polyproline region of the CD95 ligand: Hints for the reverse signal transduction capacity of a death factor1. FEBS Lett. 2001, 509, 255-262. [CrossRef]

38. Wei, H.; Chen, Q.; Lin, L.; Sha, C.; Li, T.; Liu, Y.; Yin, X.; Xu, Y.; Chen, L.; Gao, W.; et al. Regulation of exosome production and cargo sorting. Int. J. Biol. Sci. 2021, 17, 163-177. [CrossRef] [PubMed]

39. Boonacker, E.; Van Noorden, C.J.F. The multifunctional or moonlighting protein CD26/DPPIV. Eur. J. Cell Biol. $2003,82,53-73$. [CrossRef]

40. Kameoka, J.; Tanaka, T.; Nojima, Y.; Schlossman, S.F.; Morimoto, C. Direct Association of Adenosine Deaminase with a T Cell Activation Antigen, CD26. Science 1993, 261, 466-469. [CrossRef]

41. Ohnuma, K.; Yamochi, T.; Uchiyama, M.; Nishibashi, K.; Yoshikawa, N.; Shimizu, N.; Iwata, S.; Tanaka, H.; Dang, N.H.; Morimoto, C. CD26 up-regulates expression of CD86 on antigen-presenting cells by means of caveolin-1. Proc. Natl. Acad. Sci. USA 2004, 101, 14186-14191. [CrossRef] [PubMed]

42. Ishii, T.; Ohnuma, K.; Murakami, A.; Takasawa, N.; Kobayashi, S.; Dang, N.H.; Schlossman, S.F.; Morimoto, C. CD26-mediated signaling for T cell activation occurs in lipid rafts through its association with CD45RO. Proc. Natl. Acad. Sci. USA 2001, 98, 12138-12143. [CrossRef] [PubMed]

43. Torimoto, Y.; Dang, N.H.; Vivier, E.; Tanaka, T.; Schlossman, S.F.; Morimoto, C. Coassociation of CD26 (dipeptidyl peptidase IV) with CD45 on the surface of human T lymphocytes. J. Immunol. 1991, 147, 2514-2517.

44. Herrera, C.; Morimoto, C.; Blanco, J.; Mallol, J.; Arenzana, F.; Lluis, C.; Franco, R. Comodulation of CXCR4 and CD26 in Human Lymphocytes. J. Biol. Chem. 2001, 276, 19532-19539. [CrossRef]

45. Loster, K.; Zeilinger, K.; Schuppan, D.; Reutter, W. The Cysteine-Rich Region of Dipeptidyl Peptidase IV (CD 26) Is the Collagen Binding Site. Biochem. Biophys. Res. Commun. 1995, 217, 341-348. [CrossRef]

46. Cheng, H.-C.; Abdel-Ghany, M.; Pauli, B.U. A Novel Consensus Motif in Fibronectin Mediates Dipeptidyl Peptidase IV Adhesion and Metastasis. J. Biol. Chem. 2003, 278, 24600-24607. [CrossRef] 
47. Davoodi, J.; Kelly, J.; Gendron, N.H.; MacKenzie, A.E. The Simpson-Golabi-Behmel syndrome causative Glypican-3, binds to and inhibits the dipeptidyl peptidase activity of CD26. Proteomics 2007, 7, 2300-2310. [CrossRef] [PubMed]

48. Ohnuma, K.; Uchiyama, M.; Hatano, R.; Takasawa, W.; Endo, Y.; Dang, N.H.; Morimoto, C. Blockade of CD26-mediated T cell costimulation with soluble caveolin-1-Ig fusion protein induces anergy in CD4+T cells. Biochem. Biophys. Res. Commun. 2009, 386, 327-332. [CrossRef]

49. Ikushima, H.; Munakata, Y.; Iwata, S.; Ohnuma, K.; Kobayashi, S.; Dang, N.H.; Morimoto, C. Soluble CD26/dipeptidyl peptidase IV enhances transendothelial migration via its interaction with mannose 6-phosphate/insulin-like growth factor II receptor. Cell. Immunol. 2002, 215, 106-110. [CrossRef]

50. Vankadari, N.; Wilce, J.A. Emerging COVID-19 coronavirus: Glycan shield and structure prediction of spike glycoprotein and its interaction with human CD26. Emerg. Microbes Infect. 2020, 9, 601-604. [CrossRef]

51. Lu, G.; Hu, Y.; Wang, Q.; Qi, J.; Gao, F.; Li, Y.; Zhang, Y.; Zhang, W.; Yuan, Y.; Bao, J.; et al. Molecular basis of binding between novel human coronavirus MERS-CoV and its receptor CD26. Nature 2013, 500, 227-231. [CrossRef]

52. Schon, E.; DeMuth, H.-U.; Eichmann, E.; Horst, H.-J.; Korner, H.-J.; Kopp, J.; Mattern, T.; Neubert, K.; Noll, F.; Ulmer, A.J.; et al. Dipeptidyl Peptidase IV in Human T Lymphocytes. Impaired induction of interleukin 2 and gamma interferon due to specific inhibition of dipeptidyl peptidase IV. Scand. J. Immunol. 1989, 29, 127-132. [CrossRef] [PubMed]

53. Hegen, M.; Kameoka, J.; Dong, R.-P.; Schlossman, S.F.; Morimoto, C. Cross-linking of CD26 by antibody induces tyrosine phosphorylation and activation of mitogen-activated protein kinase. Immunology 1997, 90, 257-264. [CrossRef] [PubMed]

54. Sauer, A.V.; Brigida, I.; Carriglio, N.; Aiuti, A. Autoimmune Dysregulation and Purine Metabolism in Adenosine Deaminase Deficiency. Front. Immunol. 2012, 3, 265. [CrossRef]

55. Cekic, C.; Linden, J. Purinergic regulation of the immune system. Nat. Rev. Immunol. 2016, 16, 177-192. [CrossRef]

56. Dong, R.P.; Kameoka, J.; Hegen, M.; Tanaka, T.; Xu, Y.; Schlossman, S.F.; Morimoto, C. Characterization of adenosine deaminase binding to human CD26 on T cells and its biologic role in immune response. J. Immunol. 1996, 156, 1349-1355.

57. Martinez-Navio, J.M.; Casanova, V.; Pacheco, R.; Naval-Macabuhay, I.; Climent, N.; Garcia, F.; Gatell, J.M.; Mallol, J.; Gallart, T.; Lluis, C.; et al. Adenosine deaminase potentiates the generation of effector, memory, and regulatory CD4+T cells. J. Leukoc. Biol. 2010, 89, 127-136. [CrossRef]

58. Pacheco, R.; Martinez-Navio, J.M.; Lejeune, M.; Climent, N.; Oliva, H.; Gatell, J.M.; Gallart, T.; Mallol, J.; Lluis, C.; Franco, R. CD26, adenosine deaminase, and adenosine receptors mediate costimulatory signals in the immunological synapse. Proc. Natl. Acad. Sci. USA 2005, 102, 9583-9588. [CrossRef] [PubMed]

59. Wragg, K.M.; Tan, H.X.; Kristensen, A.B.; Nguyen-Robertson, C.V.; Kelleher, A.D.; Parsons, M.S.; Wheatley, A.K.; Berzins, S.P.; Pellicci, D.G.; Kent, S.J.; et al. High CD26 and Low CD94 Expression Identifies an IL-23 Responsive V82+ T Cell Subset with a MAIT Cell-like Transcriptional Profile. Cell Rep. 2020, 31, 107773. [CrossRef]

60. Yu, D.M.T.; Slaitini, L.; Gysbers, V.; Riekhoff, A.G.M.; Kähne, T.; Knott, H.M.; De Meester, I.; Abbott, C.A.; Mccaughan, G.; Gorrell, M.D. Soluble CD26/Dipeptidyl Peptidase IV Enhances Human Lymphocyte Proliferation In Vitro Independent of Dipeptidyl Peptidase Enzyme Activity and Adenosine Deaminase Binding. Scand. J. Immunol. 2010, 73, 102-111. [CrossRef]

61. Hatano, R.; Ohnuma, K.; Yamamoto, J.; Dang, N.H.; Morimoto, C. CD26-mediated co-stimulation in human CD8+T cells provokes effector function via pro-inflammatory cytokine production. Immunology 2013, 138, 165-172. [CrossRef]

62. Kitagawa, N.; Hamaguchi, M.; Majima, S.; Fukuda, T.; Kimura, T.; Hashimoto, Y.; Tanaka, M.; Yamazaki, M.; Nakamura, N.; Fukui, M. Dipeptidyl peptidase-4 inhibitors have adverse effects for the proliferation of human T cells. J. Clin. Biochem. Nutr. 2018, 63, 106-112. [CrossRef] [PubMed]

63. Tian, L.; Gao, J.; Hao, J.; Zhang, Y.; Yi, H.; O’Brien, T.D.; Sorenson, R.; Luo, J.; Guo, Z. Reversal of New-Onset Diabetes through Modulating Inflammation and Stimulating $\beta$-Cell Replication in Nonobese Diabetic Mice by a Dipeptidyl Peptidase IV Inhibitor. Endocrinology 2010, 151, 3049-3060. [CrossRef] [PubMed]

64. Vora, K.A.; Porter, G.; Peng, R.; Cui, Y.; Pryor, K.; Eiermann, G.; Zaller, D.M. Genetic ablation or pharmacological blockade of dipeptidyl peptidase IV does not impact T cell-dependent immune responses. BMC Immunol. 2009, 10, 19. [CrossRef]

65. Lankas, G.R.; Leiting, B.; Roy, R.S.; Eiermann, G.J.; Beconi, M.G.; Biftu, T.; Chan, C.-C.; Edmondson, S.; Feeney, W.P.; He, H.; et al. Dipeptidyl Peptidase IV Inhibition for the Treatment of Type 2 Diabetes: Potential Importance of Selectivity Over Dipeptidyl Peptidases 8 and 9. Diabetes 2005, 54, 2988-2994. [CrossRef]

66. Rohrborn, D.; Wronkowitz, N.; Eckel, J. DPP4 in Diabetes. Front. Immunol. 2015, 6, 386. [CrossRef]

67. Wei, J.; Raynor, J.; Nguyen, T.-L.M.; Chi, H. Nutrient and Metabolic Sensing in T Cell Responses. Front. Immunol. 2017, 8, 247. [CrossRef]

68. Pearce, E.L.; Poffenberger, M.C.; Chang, C.-H.; Jones, R.G. Fueling Immunity: Insights into Metabolism and Lymphocyte Function. Science 2013, 342, 1242454. [CrossRef] [PubMed]

69. Sanchez, J.; Jackson, I.; Flaherty, K.R.; Muliaditan, T.; Schurich, A. Divergent Impact of Glucose Availability on Human VirusSpecific and Generically Activated CD8 T Cells. Metabolites 2020, 10, 461. [CrossRef] [PubMed]

70. Britton, C.; Poznansky, M.C.; Reeves, P. Polyfunctionality of the CXCR4/CXCL12 axis in health and disease: Implications for therapeutic interventions in cancer and immune-mediated diseases. FASEB J. 2021, 35, e21260. [CrossRef]

71. Shioda, T.; Kato, H.; Ohnishi, Y.; Tashiro, K.; Ikegawa, M.; Nakayama, E.E.; Hu, H.; Kato, A.; Sakai, Y.; Liu, H.; et al. Anti-HIV-1 and chemotactic activities of human stromal cell-derived factor 1 (SDF-1) and SDF-1 are abolished by CD26/dipeptidyl peptidase IV-mediated cleavage. Proc. Natl. Acad. Sci. USA 1998, 95, 6331-6336. [CrossRef] 
72. Crump, M.P.; Gong, J.-H.; Loetscher, P.; Rajarathnam, K.; Amara, A.; Arenzana-Seisdedos, F.; Virelizier, J.; Baggiolini, M.; Sykes, B.D.; Clark-Lewis, I. Solution structure and basis for functional activity of stromal cell-derived factor-1; dissociation of CXCR4 activation from binding and inhibition of HIV-1. EMBO J. 1997, 16, 6996-7007. [CrossRef] [PubMed]

73. Decalf, J.; Tarbell, K.V.; Casrouge, A.; Price, J.D.; Linder, G.; Mottez, E.; Sultanik, P.; Mallet, V.; Pol, S.; Duffy, D.; et al. Inhibition of DPP 4 activity in humans establishes its in vivo role in CXCL 10 post-translational modification: Prospective placebo-controlled clinical studies. EMBO Mol. Med. 2016, 8, 679-683. [CrossRef] [PubMed]

74. Proost, P.; Meester, I.; de Schols, D.; Struyf, S.; Lambeir, A.M.; Wuyts, A.; Opdenakker, G.; Clercq, E.; de Scharpé, S.; van Damme, J. Amino-terminal truncation of chemokines by CD26/dipeptidyl-peptidase IV. Conversion of RANTES into a potent inhibitor of monocyte chemotaxis and HIV-1-infection. J. Biol. Chem. 1998, 13, 7222-7227. [CrossRef] [PubMed]

75. Iwata, S.; Yamaguchi, N.; Munakata, Y.; Ikushima, H.; Lee, J.F.; Hosono, O.; Schlossman, S.F.; Morimoto, C. CD26/dipeptidyl peptidase IV differentially regulates the chemotaxis of T cells and monocytes toward RANTES: Possible mechanism for the switch from innate to acquired immune response. Int. Immunol. 1999, 11, 417-426. [CrossRef]

76. De Zutter, A.; Van Damme, J.; Struyf, S. The Role of Post-Translational Modifications of Chemokines by CD26 in Cancer. Cancers 2021, 13, 4247. [CrossRef]

77. Klune, J.R.; Dhupar, R.; Cardinal, J.; Billiar, T.R.; Tsung, A. HMGB1: Endogenous Danger Signaling. Mol. Med. 2008, 14, 476-484. [CrossRef]

78. Lotze, M.T.; Tracey, K.J. High-mobility group box 1 protein (HMGB1): Nuclear weapon in the immune arsenal. Nat. Rev. Immunol. 2005, 5, 331-342. [CrossRef]

79. Wang, H.; Bloom, O.; Zhang, M.; Vishnubhakat, J.M.; Ombrellino, M.; Che, J.; Frazier, A.; Yang, H.; Ivanova, S.; Borovikova, L.; et al. HMG-1 as a Late Mediator of Endotoxin Lethality in Mice. Science 1999, 285, 248-251. [CrossRef]

80. Saidi, H.; Melki, M.-T.; Gougeon, M.-L. HMGB1-Dependent Triggering of HIV-1 Replication and Persistence in Dendritic Cells as a Consequence of NK-DC Cross-Talk. PLoS ONE 2008, 3, e3601. [CrossRef]

81. Yang, D.; Chen, Q.; Yang, H.; Tracey, K.J.; Bustin, M.; Oppenheim, J.J. High mobility group box-1 protein induces the migration and activation of human dendritic cells and acts as an alarmin. J. Leukoc. Biol. 2006, 81, 59-66. [CrossRef]

82. Apetoh, L.; Ghiringhelli, F.; Tesniere, A.; Obeid, M.; Ortiz, C.; Criollo, A.; Mignot, G.; Maiuri, M.C.; Ullrich, E.; Saulnier, P.; et al. Toll-like receptor 4-dependent contribution of the immune system to anticancer chemotherapy and radiotherapy. Nat. Med. 2007, 13, 1050-1059. [CrossRef]

83. Gdynia, G.; Sauer, S.W.; Kopitz, J.; Fuchs, D.; Duglova, K.; Ruppert, T.; Miller, M.; Pahl, J.; Cerwenka, A.; Enders, M.; et al. The HMGB1 protein induces a metabolic type of tumour cell death by blocking aerobic respiration. Nat. Commun. 2016, 7, 10764. [CrossRef]

84. Gdynia, G.; Keith, M.; Kopitz, J.; Bergmann, M.; Fassl, A.; Weber, A.N.R.; George, J.; Kees, T.; Zentgraf, H.-W.; Wiestler, O.D.; et al. Danger Signaling Protein HMGB1 Induces a Distinct Form of Cell Death Accompanied by Formation of Giant Mitochondria. Cancer Res. 2010, 70, 8558-8568. [CrossRef]

85. Zetterström, C.K.; Bergman, T.; Rynnel-Dagöö, B.; Harris, H.E.; Söder, O.; Andersson, U.; Boman, H.G. High Mobility Group Box Chromosomal Protein 1 (HMGB1) Is an Antibacterial Factor Produced by the Human Adenoid. Pediatr. Res. 2002, 52, 148-154. [CrossRef]

86. Kwak, M.S.; Kim, H.S.; Lee, B.; Kim, Y.H.; Son, M.; Shin, J.-S. Immunological Significance of HMGB1 Post-Translational Modification and Redox Biology. Front. Immunol. 2020, 11, 1189. [CrossRef]

87. Marchetti, C.; Di Carlo, A.; Facchiano, F.; Senatore, C.; De Cristofaro, R.; Luzi, A.; Federici, M.; Romani, M.; Napolitano, M.; Capogrossi, M.C.; et al. High mobility group box 1 is a novel substrate of dipeptidyl peptidase-IV. Diabetologia 2011, 55, 236-244. [CrossRef]

88. Willheim, M.; Ebner, C.; Kern, W.; Schrattbauer, K.; Theina, R.; Kraft, D.; Breiteneder, H.; Reinisch, W.; Scheiner, O. Cell surface characterization of T lymphocytes and allergen-specific T cell clones: Correlation of CD26 expression with T H1 subsets. J. Allergy Clin. Immunol. 1997, 100, 348-355. [CrossRef]

89. Zhao, X.; Wang, W.; Zhang, K.; Yang, J.; Fuchs, H.; Fan, H. Involvement of CD26 in Differentiation and Functions of Th1 and Th17 Subpopulations of T Lymphocytes. J. Immunol. Res. 2021, 2021, 6671410. [CrossRef]

90. Nelson, M.H.; Knochelmann, H.M.; Bailey, S.R.; Huff, L.W.; Bowers, J.S.; Majchrzak-Kuligowska, K.; Wyatt, M.M.; Rubinstein, M.P.; Mehrotra, S.; Nishimura, M.I.; et al. Identification of human CD4 + T cell populations with distinct antitumor activity. Sci. Adv. 2020, 6, eaba7443. [CrossRef]

91. Bailey, S.R.; Nelson, M.H.; Majchrzak, K.; Bowers, J.S.; Wyatt, M.M.; Smith, A.S.; Neal, L.R.; Shirai, K.; Carpenito, C.; June, C.H.; et al. Human CD26high T cells elicit tumor immunity against multiple malignancies via enhanced migration and persistence. Nat. Commun. 2017, 8, 1961. [CrossRef] [PubMed]

92. Wyatt, M.M.; Bailey, S.; Knochelmann, H.; Smith, A.S.; Dwyer, C.; Rivera, G.O.R.; Reyes, A.R.; Nelson, M.; Paulos, C.M. CD26 enzymatic activity modulates efficient migration of adoptively transferred cancer-specific T cells to solid tumors. J. Immunol. 2020, 1, 72-17.

93. Knochelmann, H.M.; Arhontoulis, D.; Rivera-Reyes, A.; Wyatt, M.; Neskey, D.; Paulos, C. CD26 in checkpoint blockade-induced tumor immunity. Int. J. Radiat. Oncol. 2020, 106, 1132. [CrossRef]

94. Nishikawa, H.; Sakaguchi, S. Regulatory T cells in tumor immunity. Int. J. Cancer 2010, 127, 759-767. [CrossRef] [PubMed] 
95. Salgado, F.J.; Pérez-Díaz, A.; Villanueva, N.M.; Lamas, O.; Arias, P.; Nogueira, M. CD26: A negative selection marker for human Treg cells. Cytom. Part A 2012, 81A, 843-855. [CrossRef]

96. Eohta, A.; Esitkovsky, M. Extracellular Adenosine-Mediated Modulation of Regulatory T Cells. Front. Immunol. 2014, 5, 304. [CrossRef]

97. Oderup, C.; Cederbom, L.; Makowska, A.; Cilio, C.M.; Ivars, F. Cytotoxic T lymphocyte antigen-4-dependent down-modulation of costimulatory molecules on dendritic cells in CD4+ CD25+ regulatory T-cell-mediated suppression. Immunology 2006, 118, 240-249. [CrossRef] [PubMed]

98. Rudy, W.; Gückel, B.; Siebels, M.; Lindauer, M.; Meuer, S.C.; Moebius, U. Differential function of CD80- and CD86-transfected human melanoma cells in the presence of IL-12 and IFN-gamma. Int. Immunol. 1997, 9, 853-860. [CrossRef]

99. Zheng, Y.; Manzotti, C.N.; Liu, M.; Burke, F.; Mead, K.I.; Sansom, D.M. CD86 and CD80 Differentially Modulate the Suppressive Function of Human Regulatory T Cells. J. Immunol. 2004, 172, 2778-2784. [CrossRef]

100. Dang, N.H.; Morimoto, C. CD26: An expanding role in immune regulation and cancer. Histol. Histopathol. 2002, 4, 1213-1226. [CrossRef]

101. Lam, C.S.-C.; Cheung, A.H.-K.; Wong, S.K.-M.; Wan, T.M.-H.; Ng, L.; Chow, A.K.-M.; Cheng, N.S.-M.; Pak, R.C.-H.; Li, H.-S.; Man, J.H.-W.; et al. Prognostic Significance of CD26 in Patients with Colorectal Cancer. PLoS ONE 2014, 9, e98582. [CrossRef]

102. Takeda, M.; Ohe, Y.; Horinouchi, H.; Hida, T.; Shimizu, J.; Seto, T.; Nosaki, K.; Kishimoto, T.; Miyashita, I.; Yamada, M.; et al. Phase I study of YS110, a recombinant humanized monoclonal antibody to CD26, in Japanese patients with advanced malignant pleural mesothelioma. Lung Cancer 2019, 137, 64-70. [CrossRef]

103. Angevin, E.; Isambert, N.; Trillet-Lenoir, V.; You, B.; Alexandre, J.; Zalcman, G.; Vielh, P.; Farace, F.; Valleix, F.; Podoll, T.; et al. First-in-human phase 1 of YS110, a monoclonal antibody directed against CD26 in advanced CD26-expressing cancers. Br. J. Cancer 2017, 116, 1126-1134. [CrossRef] [PubMed]

104. Enz, N.; Vliegen, G.; De Meester, I.; Jungraithmayr, W. CD26/DPP4-A potential biomarker and target for cancer therapy. Pharmacol. Ther. 2019, 198, 135-159. [CrossRef] [PubMed]

105. Beckenkamp, A.; Davies, S.; Willig, J.B.; Buffon, A. DPPIV/CD26: A tumor suppressor or a marker of malignancy? Tumor Biol. 2016, 37, 7059-7073. [CrossRef] [PubMed]

106. Wesley, U.V.; Tiwari, S.; Houghton, A.N. Role for dipeptidyl peptidase IV in tumor suppression of human non small cell lung carcinoma cells. Int. J. Cancer 2004, 109, 855-866. [CrossRef]

107. Arscott, W.T.; LaBauve, A.E.; May, V.; Wesley, U.V. Suppression of neuroblastoma growth by dipeptidyl peptidase IV: Relevance of chemokine regulation and caspase activation. Oncogene 2008, 28, 479-491. [CrossRef]

108. Carbone, A.; Gloghini, A.; Zagonel, V.; Aldinucci, D.; Gattei, V.; Degan, M.; Improta, S.; Sorio, R.; Monfardini, S.; Pinto, A. The expression of CD26 and CD40 ligand is mutually exclusive in human T-cell non-Hodgkin's lymphomas/leukemias. Blood 1995, 12, 4617-4626. [CrossRef]

109. Sato, T.; Yamochi, T.; Yamochi, T.; Aytac, U.; Ohnuma, K.; McKee, K.S.; Morimoto, C.; Dang, N.H. CD26 Regulates p38 MitogenActivated Protein Kinase-Dependent Phosphorylation of Integrin 1, Adhesion to Extracellular Matrix, and Tumorigenicity of T-Anaplastic Large Cell Lymphoma Karpas 299. Cancer Res. 2005, 65, 6950-6956. [CrossRef]

110. Lee, M.; Sun, J.; Han, M.; Cho, Y.; Lee, J.-Y.; Nam, C.M.; Kang, E.S. Nationwide Trends in Pancreatitis and Pancreatic Cancer Risk Among Patients With Newly Diagnosed Type 2 Diabetes Receiving Dipeptidyl Peptidase 4 Inhibitors. Diabetes Care 2019, 42 , 2057-2064. [CrossRef]

111. Boniol, M.; Franchi, M.; Bota, M.; Leclercq, A.; Guillaume, J.; van Damme, N.; Corrao, G.; Autier, P.; Boyle, P. Incretin-Based Therapies and the Short-term Risk of Pancreatic Cancer: Results From Two Retrospective Cohort Studies. Diabetes Care 2017, 41, 286-292. [CrossRef]

112. Tseng, C.-H. Sitagliptin use and thyroid cancer risk in patients with type 2 diabetes. Oncotarget 2016, 7, 24871-24879. [CrossRef] [PubMed]

113. Pan, K.; Skelton, W.P.; Elzeneini, M.; Nguyen, T.-C.; Franke, A.J.; Ali, A.; Bishnoi, R.; Dang, L.; Dang, N.H.; Kish, J. A Multi-Center Retrospective Analysis Examining the Effect of Dipeptidyl Peptidase-4 Inhibitors on Progression-Free Survival in Patients With Prostate Cancer. Cureus 2021, 4, e14712. [CrossRef]

114. Dicembrini, I.; Nreu, B.; Montereggi, C.; Mannucci, E.; Monami, M. Risk of cancer in patients treated with dipeptidyl peptidase-4 inhibitors: An extensive meta-analysis of randomized controlled trials. Acta Diabetol. 2020, 57, 689-696. [CrossRef] [PubMed]

115. Ueki, K.; Tanizawa, Y.; Nakamura, J.; Yamada, Y.; Inagaki, N.; Watada, H.; Shimomura, I.; Nishimura, R.; Miyoshi, H.; Abiko, A.; et al. Long-term safety and efficacy of alogliptin, a DPP-4 inhibitor, in patients with type 2 diabetes: A 3-year prospective, controlled, observational study (J-BRAND Registry). BMJ Open Diabetes Res. Care 2021, 9, e001787. [CrossRef] [PubMed]

116. Ali, A.; Fuentes, A.; Iv, W.P.S.; Wang, Y.; McGorray, S.; Shah, C.; Bishnoi, R.; Dang, L.H.; Dang, N.H. A multi-center retrospective analysis of the effect of DPP4 inhibitors on progression-free survival in advanced airway and colorectal cancers. Mol. Clin. Oncol. 2018, 10, 118-124. [CrossRef] [PubMed]

117. Bishnoi, R.; Hong, Y.-R.; Shah, C.; Ali, A.; Skelton, W.P.; Huo, J.; Dang, N.H.; Dang, L.H. Dipeptidyl peptidase 4 inhibitors as novel agents in improving survival in diabetic patients with colorectal cancer and lung cancer: A Surveillance Epidemiology and Endpoint Research Medicare study. Cancer Med. 2019, 8, 3918-3927. [CrossRef]

118. Choi, Y.J.; Kim, D.J.; Shin, S. Incident cancer risk in dipeptidyl peptidase-4 inhibitor-treated patients with type 2 diabetes mellitus. Cancer Manag. Res. 2019, ume 11,7427-7438. [CrossRef] 
119. De Andrade, C.F.C.G.; Bigni, R.; Pombo-de-Oliveira, M.S.; Alves, G.; Pereira, D.A. CD26/DPPIV cell membrane expression and DPPIV activity in plasma of patients with acute leukemia. J. Enzym. Inhib. Med. Chem. 2009, 24, 708-714. [CrossRef]

120. Narducci, M.G.; Scala, E.; Bresin, A.; Caprini, E.; Picchio, M.C.; Remotti, D.; Ragone, G.; Nasorri, F.; Frontani, M.; Arcelli, D.; et al. Skin homing of Seézary cells involves SDF-1-CXCR4 signaling and down-regulation of CD26/dipeptidylpeptidase IV. Blood 2006, 107, 1108-1115. [CrossRef]

121. Miyagaki, T.; Sugaya, M.; Suga, H.; Morimura, S.; Kamata, M.; Ohmatsu, H.; Fujita, H.; Asano, Y.; Tada, Y.; Kadono, T.; et al. Serum soluble CD26 levels: Diagnostic efficiency for atopic dermatitis, cutaneous T-cell lymphoma and psoriasis in combination with serum thymus and activation-regulated chemokine levels. J. Eur. Acad. Dermatol. Venereol. 2011, 27, 19-24. [CrossRef] [PubMed]

122. Scala, E.; Cadoni, S.; Girardelli, C.R.; De Pità, O.; Puddu, P.; Russo, G.; Narducci, M.G. Skewed Expression of Activation, Differentiation and Homing-Related Antigens in Circulating Cells from Patients with Cutaneous T Cell Lymphoma Associated with CD7- T Helper Lymphocytes Expansion. J. Investig. Dermatol. 1999, 113, 622-627. [CrossRef] [PubMed]

123. Hristov, A.C.; Vonderheid, E.C.; Borowitz, M.J. Simplified Flow Cytometric Assessment in Mycosis Fungoides and Sézary Syndrome. Am. J. Clin. Pathol. 2011, 136, 944-953. [CrossRef] [PubMed]

124. Novelli, M.; Comessatti, A.; Quaglino, P.; Savoia, P.; Fierro, M.T.; Bernengo, M.G. CD26 Expression on Cutaneous Infiltrates from Patients with Cutaneous T-Cell Lymphoma (CTCL) CD26 in cutaneous T-cell lymphoma patients. Adv. Exp. Med. Biol. 2003, 524, 223-234. [CrossRef]

125. Abeni, D.; Frontani, M.; Sampogna, F.; Sera, F.; Bolli, S.; Corona, R.; Baliva, G.; Russo, G. Circulating CD8+ lymphocytes, white blood cells, and survival in patients with mycosis fungoides. Br. J. Dermatol. 2005, 153, 324-330. [CrossRef]

126. Torrealba, M.P.; Manfrere, K.C.; Miyashiro, D.R.; Lima, J.F.; Oliveira, L.D.M.; Pereira, N.Z.; Cury-Martins, J.; Pereira, J.; Duarte, A.J.S.; Sato, M.N.; et al. Chronic activation profile of circulating CD8+ T cells in Sézary syndrome. Oncotarget 2017, 9, 3497-3506. [CrossRef]

127. Novelli, M.M.; Fava, P.; Sarda, C.; Ponti, M.R.; Osella-Abate, M.S.; Savoia, P.; Bergallo, M.M.; Lisa, M.F.; Fierro, M.T.; Quaglino, P. Blood Flow Cytometry in Sézary Syndrome. Am. J. Clin. Pathol. 2015, 143, 57-69. [CrossRef]

128. Kelemen, K.; Guitart, J.; Kuzel, T.M.; Goolsby, C.L.; Peterson, L.C. The Usefulness of CD26 in Flow Cytometric Analysis of Peripheral Blood in Sézary Syndrome. Am. J. Clin. Pathol. 2008, 129, 146-156. [CrossRef] [PubMed]

129. Sokolowska-Wojdylo, M.; Wenzel, J.; Gaffal, E.; Steitz, J.; Roszkiewicz, J.; Bieber, T.; Tuting, T. Absence of CD26 expression on skin-homing CLA+ CD4+ T lymphocytes in peripheral blood is a highly sensitive marker for early diagnosis and therapeutic monitoring of patients with Sezary syndrome. Clin. Exp. Dermatol. 2005, 30, 702-706. [CrossRef] [PubMed]

130. Bernengo, M.G.; Novelli, M.; Quaglino, P.; Lisa, F.; De Matteis, A.; Savoia, P.; Cappello, N.; Fierro, M.T. The relevance of the CD4+ CD26- subset in the identification of circulating Sézary cells. Br. J. Dermatol. 2001, 144, 125-135. [CrossRef]

131. Jones, D.; Dang, N.H.; Duvic, M.; Washington, L.T.; Huh, Y.O. Absence of CD26 Expression Is a Useful Marker for Diagnosis of T-Cell Lymphoma in Peripheral Blood. Am. J. Clin. Pathol. 2001, 115, 885-892. [CrossRef] [PubMed]

132. Saulite, I.; Ignatova, D.; Chang, Y.-T.; Fassnacht, C.; Dimitriou, F.; Varypataki, E.; Anzengruber, F.; Nägeli, M.; Cozzio, A.; Dummer, R.; et al. Blockade of programmed cell death protein 1 (PD-1) in Sézary syndrome reduces Th2 phenotype of non-tumoral T lymphocytes but may enhance tumor proliferation. OncoImmunology 2020, 9, 1738797. [CrossRef] [PubMed]

133. Wood, G.S.; Hong, S.R.; Sasaki, D.T.; Abel, E.A.; Hoppe, R.T.; Warnke, R.A.; Morhenn, V.B. Leu-8/CD7 antigen expression by CD3+ T cells: Comparative analysis of skin and blood in mycosis fungoides/Sézary syndrome relative to normal blood values. J. Am. Acad. Dermatol. 1990, 22, 602-607. [CrossRef]

134. Vonderheid, E.C.; Hou, J.S. CD4+CD26-lymphocytes are useful to assess blood involvement and define B ratings in cutaneous T cell lymphoma. Leuk. Lymphoma 2017, 59, 330-339. [CrossRef]

135. Olsen, E.; Vonderheid, E.; Pimpinelli, N.; Willemze, R.; Kim, Y.; Knobler, R.; Zackheim, H.; Duvic, M.; Estrach, T.; Lamberg, S.; et al. Revisions to the staging and classification of mycosis fungoides and Sézary syndrome: A proposal of the International Society for Cutaneous Lymphomas (ISCL) and the cutaneous lymphoma task force of the European Organization of Research and Treatment of Cancer (EORTC). Blood 2007, 110, 1713-1722. [CrossRef]

136. Scarisbrick, J.J.; Hodak, E.; Bagot, M.; Stranzenbach, R.; Stadler, R.; Ortiz-Romero, P.L.; Papadavid, E.; Evison, F.; Knobler, R.; Quaglino, P.; et al. Blood classification and blood response criteria in mycosis fungoides and Sézary syndrome using flow cytometry: Recommendations from the EORTC cutaneous lymphoma task force. Eur. J. Cancer 2018, 93, 47-56. [CrossRef]

137. Cordero, O.J.; Varela-Calvino, R.; López-González, T.; Calviño-Sampedro, C.; Viñuela, J.E.; Mouriño, C.; Hernández-Rodríguez, Í.; Rodríguez-López, M.; De La Iglesia, B.A.; Pego-Reigosa, J.M. CD26 Expression on T Helper Populations and sCD26 Serum Levels in Patients with Rheumatoid Arthritis. PLoS ONE 2015, 10, e0131992. [CrossRef]

138. Cedeno-Laurent, F.; Wysocka, M.; Weng, W.-K.; Obstfeld, A.E.; Novoa, R.A.; Vittorio, C.C.; Kim, E.J.; Rook, A.H. Gain of CD26 expression on the malignant T-cells in relapsed erythrodermic leukemic mycosis fungoides. J. Cutan. Pathol. 2017, 44, 462-466. [CrossRef] [PubMed]

139. Vural, S.; Akay, B.N.; Botsalı, A.; Atilla, E.; Parlak, N.; Heper, A.O.; Şanlı, H. Transformation of Mycosis Fungoides/Sezary Syndrome: Clinical Characteristics and Prognosis. Turk. J. Hematol. 2018, 35, 35-41. [CrossRef] [PubMed]

140. Vandersee, S.; Humme, D.; Terhorst, D.; Almohamad, A.; Möbs, M.; Beyer, M. Evaluation of blood parameters for the monitoring of erythrodermic cutaneous T-cell lymphoma. J. der Dtsch. Dermatol. Ges. 2015, 13, 30-35. [CrossRef] [PubMed] 